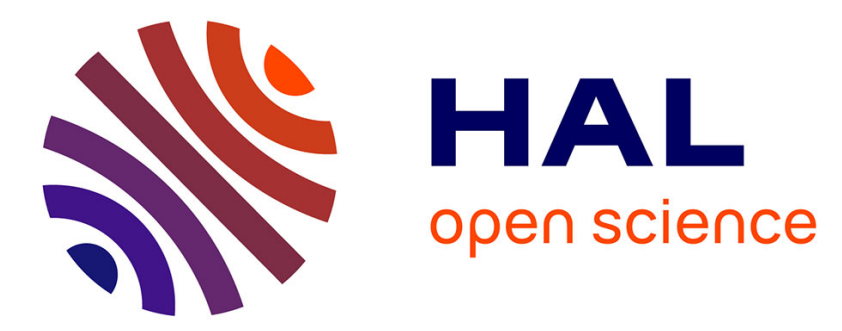

\title{
DNA interactions of 2-pyrrolinodoxorubicin, a distinctively more potent daunosamine-modified analog of doxorubicin
}

Jana Stepankova, Martin Studenovsky, Jaroslav Malina, Jana Kasparkova, Barbora Liskova, Olga Novakova, Karel Ulbrich, Viktor Brabec

\section{To cite this version:}

Jana Stepankova, Martin Studenovsky, Jaroslav Malina, Jana Kasparkova, Barbora Liskova, et al.. DNA interactions of 2-pyrrolinodoxorubicin, a distinctively more potent daunosamine-modified analog of doxorubicin. Biochemical Pharmacology, 2011, 82 (3), pp.227. 10.1016/j.bcp.2011.04.010 . hal00711296

\section{HAL Id: hal-00711296 \\ https://hal.science/hal-00711296}

Submitted on 23 Jun 2012

HAL is a multi-disciplinary open access archive for the deposit and dissemination of scientific research documents, whether they are published or not. The documents may come from teaching and research institutions in France or abroad, or from public or private research centers.
L'archive ouverte pluridisciplinaire HAL, est destinée au dépôt et à la diffusion de documents scientifiques de niveau recherche, publiés ou non, émanant des établissements d'enseignement et de recherche français ou étrangers, des laboratoires publics ou privés. 


\section{Accepted Manuscript}

Title: DNA interactions of 2-pyrrolinodoxorubicin, a distinctively more potent daunosamine-modified analog of doxorubicin

Authors: Jana Stepankova, Martin Studenovsky, Jaroslav Malina, Jana Kasparkova, Barbora Liskova, Olga Novakova,

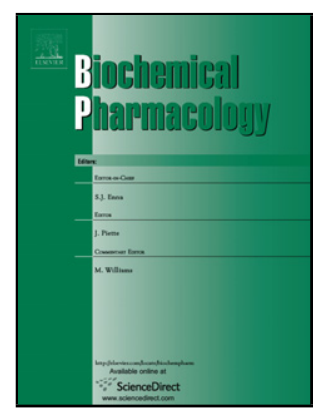

Karel Ulbrich, Viktor Brabec

PII:

S0006-2952(11)00283-8

DOI: doi:10.1016/j.bcp.2011.04.010

Reference: BCP 10882

To appear in: $\quad B C P$

Received date: $\quad$ 25-2-2011

Revised date: $\quad 3-4-2011$

Accepted date: $\quad$ 26-4-2011

Please cite this article as: Stepankova J, Studenovsky M, Malina J, Kasparkova J, Liskova B, Novakova O, Ulbrich K, Brabec V, DNA interactions of 2pyrrolinodoxorubicin, a distinctively more potent daunosamine-modified analog of doxorubicin, Biochemical Pharmacology (2010), doi:10.1016/j.bcp.2011.04.010

This is a PDF file of an unedited manuscript that has been accepted for publication. As a service to our customers we are providing this early version of the manuscript. The manuscript will undergo copyediting, typesetting, and review of the resulting proof before it is published in its final form. Please note that during the production process errors may be discovered which could affect the content, and all legal disclaimers that apply to the journal pertain. 


\section{DNA interactions of 2-pyrrolinodoxorubicin, a distinctively more}

\section{potent daunosamine-modified analog of doxorubicin}

Jana Stepankova ${ }^{a}$, Martin Studenovsky ${ }^{\mathrm{b}}$, Jaroslav Malina ${ }^{\mathrm{a}}$, Jana Kasparkova ${ }^{\mathrm{c}}$, Barbora Liskova ${ }^{\mathrm{a}}$, Olga Novakova ${ }^{\mathrm{a}}$, Karel Ulbrich ${ }^{\mathrm{b}}$, Viktor Brabec ${ }^{\mathrm{a}, *}$

${ }^{a}$ Institute of Biophysics, Academy of Science of the Czech Republic, Kralovopolska 135, CZ61265 Brno, Czech Republic

${ }^{b}$ Institute of Macromolecular Chemistry, Academy of Science of the Czech Republic, Heyrovsky square 2, CZ-16206, Prague 6, Czech Republic

${ }^{c}$ Department of Biophysics, Faculty of Sciences, Palacky University, CZ-77146 Olomouc, Czech Republic

Classification: (1) Antibiotics and Chemotherapeutics

* Corresponding author at: Institute of Biophysics, Academy of Sciences of the Czech Republic, v.v.i., Kralovopolska 135, CZ-61265 Brno, Czech Republic. Tel.: +420-541517148; fax: $+420-541240499$.

E-mail address: brabec@ibp.cz (V. Brabec) 
Abbreviations: bp, base pair; CL, crosslink; CD, circular dichroism; CT, calf-thymus; DOX, doxorubicin; DTT, dithiothreitol; EtBr, ethidium bromide; KF, Klenow fragment of DNA polymerase I; LD, linear dichroism; PAA, polyacrylamide; p-DOX, 2-pyrrolinodoxorubicin; $r$, the molar ratio of a drug to nucleotide-phosphates at the onset of incubation with DNA; topoII, topoisomerase II. 


\section{ABSTRACT}

It was shown earlier that 2-pyrrolinodoxorubicin was 500-1000 times more active towards human and mouse cancer cells in vitro than parental doxorubicin. However, the biochemical factors responsible for such a large difference in potency between doxorubicin and 2-pyrrolinodoxorubicin are not clear at the molecular level. To provide this information, we have investigated in cell-free media by biochemical and biophysical methods interactions of both anthracyclines with DNA, effects of these interactions on activity of human topoisomerase II, human Bloom's syndrome helicase and prokaryotic T7 RNA polymerase, and the capability of these drugs to form DNA interstrand cross-links in formaldehyde-free medium. Experiments aimed at understanding the properties of double-helical DNA in the presence of doxorubicin and 2-pyrrolinodoxorubicin revealed only small differences in DNA modifications by these anthracyclines and resulting conformational alterations in DNA. Similarly, the ability of 2-pyrrolinodoxorubicin modifications of DNA to inhibit catalytic activity of topoisomerase II does not differ significantly from that of doxorubicin. On the other hand, we demonstrate that an important factor responsible for the markedly higher antiproliferative potency of DNA modifications by 2-pyrrolinodoxorubicin is capability of these modifications to inhibit downstream cellular processes which process DNA damaged by this drug and involve separation of complementary strands of DNA, such as DNA unwinding by helicases or RNA polymerases. In addition, the results are also consistent with the hypothesis that in particular the capability of 2-pyrrolinodoxorubicin to readily form DNA interstrand cross-links is responsible for inhibition of these processes in the cells treated with this analogue of doxorubicin.

Keywords: doxorubicin; 2-pyrrolinodoxorubicin; DNA; topoisomerase II; helicase; interstrand 
cross-links

Page 4 of 82 


\section{Introduction}

Doxorubicin (DOX, trade name Adriamycin) or hydroxyldaunorubicin (Fig. 1A), anthracycline antibiotic, is a widely used antitumor drug, which is used for the clinical treatment of a broad range of human malignancies. As far as the mechanism of biological activity is concerned, DOX rapidly enters the nucleus of cells and binds with high affinity to DNA by noncovalent intercalation between base pairs leading to inhibition of synthesis of biomacromolecules. It is generally accepted that biological effects of DOX are associated with its ability to act as a topoisomerase II (topoII) poison perturbing the religation step of this enzyme and forming the ternary DOX-DNA-topoII cleavable complex [1, 2]. In addition, biological effects of DOX have been also related to its capability to form DNA adducts, namely "virtual" interstrand cross-links (CLs) when their formation is mediated by formaldehyde [3]. Not least, generation of free radicals, leading to DNA damage or lipid peroxidation remains a further mechanism to explain the antitumor activity of DOX, although the unresolved question is whether free radicals are generated at clinically relevant concentrations of the anthracyclines and at hypoxic oxygen tension in the tumor cell [4].

The clinical use of DOX is, however, limited by severe side effects such as cardiotoxicity, myelosuppression, and development of multidrug resistance. Such limitations have led researchers to search for alternative or even more active anthracycline. One strategy for improving the efficacy of DOX has been based on the observation that formaldehyde mediates the formation of DOX-DNA adducts or interstrand CLs. In these lesions DOX is linked to one strand of DNA by a single covalent bond and to the complementary strand via an additional hydrogen bond. These discoveries were impetus for coadministration of DOX with 
formaldehyde-releasing prodrugs, such as hexamethylenetetramine [5] and for the syntheses of the DOX-formaldehyde conjugates as drug candidates that carry their own formaldehyde $[6,7]$.

If DOX forms the adduct or interstrand CL it must react with formaldehyde to form an activated Schiff base which is then able to form an aminal (N-C-N) linkage to the exocyclic amino group of guanine residues. Thus, the formaldehyde-conjugated complex is the active form of the drug. The mono-adducts form primarily at $\mathrm{G}$ of 5'-GCN-3' sequences ( $\mathrm{N}$ is any base) where the chromophore of DOX is intercalated between the $\mathrm{C}$ and $\mathrm{N}$ base pair. In addition, DOX intercalation, covalent bonding, and hydrogen bonding at the $\mathrm{C} 9$ hydroxyl combine to form a DNA interstrand CL. Based on this knowledge, a class of more potent, non-crossresistant analogs of DOX with lower cardiotoxicity was developed capable of forming an aminal adduct with an amino group of a guanine base in close vicinity to their binding site (Fig. 2). An example is 2pyrrolinodoxorubicin (p-DOX) (Fig. 1B), which has the daunosamine nitrogen incorporated in a five-membered ring. This analog of DOX proved to be 500-1000 times more active in human and mouse cancer cells than its parental compound in vitro [8].

No information is available about factors involved in the molecular mechanism underlying biological effects of p-DOX responsible for so marked enhancement of its activity compared to DOX. DNA was identified as a major target of DOX and its analogs. Therefore, first we were interested to determine whether there is a difference in DNA binding modes of DOX and p-DOX that would correspond to the marked difference in their biological effects. In addition, topoII is most frequently considered one of the primary target sites for the activity of the anthracycline antibiotics [4]. Hence, we also examined whether there is a difference corresponding to the marked difference in biological effects of DOX and p-DOX in their capability upon DNA binding to act as topoII inhibitors. Finally, several articles (e.g. refs. [2, 9-11]) also report on 
capability of anthracyclines including DOX to potently block helicases, i.e. the enzymes which are essential for the biochemical processing of double-helical DNA because of their enzymatic action of separating hydrogen-bonded complementary strands of double-helical nucleic acids [12]. Thus, these enzymes play important roles in every aspect of DNA processing, including DNA replication, transcription, and repair $[13,14]$, i.e. also in the processes undoubtedly related to biological effects of anthracyclines. Therefore, we also tested the hypothesis that downstream cellular processes which process DNA damaged by DOX or p-DOX and involve separation of complementary strands of DNA are inhibited by p-DOX more than by parental DOX in the extent corresponding to the marked difference in antiproliferative effects of these anthracyclines observed in vitro [8].

\section{Materials and methods}

\subsection{Chemicals}

Doxorubicin hydrochloride was obtained from Sigma (Prague, Czech Republic) (purity was $\geq 99.9 \%$ based on elemental trace analysis) and was used without further purification. p-DOX was prepared in the same way as described previously [8] and characterized by MALDI-TOF spectroscopy (Bruker Daltonik, Germany) [calcd. 595, found $595.98(\mathrm{M}+\mathrm{H})$ ]. The concentrations of DOX and p-DOX were determined by measuring their visible absorption and using the molar extinction coefficient $\varepsilon_{480 \mathrm{~nm}}=11500 \mathrm{~cm}^{-1} \mathrm{M}^{-1}$. Calf thymus $(\mathrm{CT}) \mathrm{DNA}(42 \% \mathrm{G}+\mathrm{C}$, mean molecular mass ca. $20000 \mathrm{kDa}$ ) was prepared and characterized as described previously [15, 16]. 
Plasmids, pSP73 and pSP73KB [2464 and 2455 base pairs (bp), respectively] were isolated according to standard procedures. Restriction endonucleases EcoRI, HpaI, NdeI, Klenow fragment of DNA polymerase I (KF), and T4 polynucleotide kinase were purchased from New England Biolabs (Beverly, MA). Agarose was from FMC BioProducts (Rockland, ME). Radioactive products were from Amersham (Arlington Heights, IL, USA). Purified Human DNA Topoisomerase II $\alpha$ (p170 form) and Topoisomerase II Assay Kit was from TopoGen (Port Orange, Florida). Ethidium bromide (EtBr), and dithiothreitol (DTT) were from Merck KgaA (Darmstadt, Germany).

\subsection{Determination of binding constants}

DNA binding constants were determined by fluorescence titration as described previously [17]. Samples were excited at $480 \mathrm{~nm}$ and emission was measured at $590 \mathrm{~nm}$. The following titrations were carried out. Fixed ligand concentration $(1 \mu \mathrm{M})$ was titrated by increasing CT DNA concentration in BPES buffer $\left(6 \mathrm{mM} \mathrm{Na}_{2} \mathrm{HPO}_{4}, 2 \mathrm{mM} \mathrm{NaH}_{2} \mathrm{PO}_{4}, 1 \mathrm{mM} \mathrm{Na} \mathrm{H}_{2}\right.$ edta, $185 \mathrm{mM}$ $\mathrm{NaCl}, \mathrm{pH}$ 7.4). In the present work the samples of DNA were upon addition of DOX or p-DOX incubated for at least $6 \mathrm{~h}$ at $37^{\circ} \mathrm{C}$ if not stated otherwise. Titration data were fit directly by nonlinear least-squares methods to get binding constants. The titration data were fitted by nonlinear regression (GraphPad Prism) to sigmoidal dose-response to get apparent equilibrium association constants.

\subsection{Viscometry}


The relative viscosity of the solutions of CT DNA at the concentration of $150 \mu \mathrm{g} \mathrm{mL}^{-1}$ in the presence of DOX or p-DOX was measured by microviscometry (AMVn Automated Micro Viscometer, Anton Paar GmbH, Austria) using a 1.6-mm capillary tube at $37^{\circ} \mathrm{C}$. Density of the solutions was measured by Density Meter DMA 4500 (Anton Paar GmbH, Austria).

\subsection{Topoisomerase II activity assay}

Topoisomerase II (topoII) enzyme activity was assessed by measuring the decatenation of kinetoplast DNA using the Topoisomerase II Assay Kit (TopoGen, Port Orange, Florida). Kinetoplast DNA (0.2 mM) was preincubated with DOX or p-DOX in phosphate buffered saline (PBS) buffer, $\mathrm{pH} 7.4$ at $37^{\circ} \mathrm{C}$ for $6 \mathrm{~h}$. The decatenation assays were performed in reaction mixtures $(20 \mu \mathrm{L})$ containing buffer A (30 mM Tris-HCl, pH 7.6, $15 \mathrm{mM}$ 2-mercaptoethanol, 8 $\mathrm{mM} \mathrm{MgCl} 2,60 \mathrm{mM} \mathrm{NaCl}$ ) and $3 \mathrm{mM} \mathrm{ATP}, 5 \mathrm{U}$ of topoII and $8 \mu \mathrm{M}$ catenated kinetoplast DNA preincubated with DOX or p-DOX; or buffer B (containing $50 \mathrm{mM}$ Tris-HCl (pH 8.0), $120 \mathrm{mM}$ $\mathrm{KCl}, 10 \mathrm{mM} \mathrm{MgCl}$, bovine serum albumin $\left(30 \mu \mathrm{g} \mathrm{mL}^{-1}\right), 0.5 \mathrm{mM}$ dithiothreitol $)$ and $0.5 \mathrm{mM}$ ATP, $1.5 \mathrm{U}$ of topoII and $20 \mu \mathrm{M}$ catenated kinetoplast DNA preincubated with DOX or p-DOX. After 30 min of incubation at $37^{\circ} \mathrm{C}$, the reaction was terminated with $2 \mu 1$ of $10 \%$ sodium dodecyl sulfate, followed by proteinase $\mathrm{K}$ treatment $(0.3 \mathrm{mg} / \mathrm{mL})$, and fenol/chloroform extraction and separated in $1 \%$ agarose gel at $4 \mathrm{~V} \mathrm{~cm}^{-1}$, room temperature; the gel contained $\mathrm{EtBr}$ $\left(0.5 \mu \mathrm{g} \mathrm{mL}^{-1}\right)$ and was submerged in TAE buffer. The reaction products were visualized under ultraviolet light and photographed. It was verified that preincubation of topoII with anthracyclines $(3 \mu \mathrm{M})$ had no effect on its activity. 


\subsection{DNA helicase activity assay}

Substrate and protein preparations: Bloom's syndrome helicase (BLM protein) was a kind gift of Dr. Lumir Krejci (Masaryk University, Brno, Czech Republic). The synthetic oligodeoxyribonucleotides used for the preparation of DNA substrates were purchased from VBC-Genomics (Vienna, Austria). The nucleotide sequences used in this study were as follows: Oligo1: 5’- TAAGAACGACGGCCAGTGCC-3', oligo2: 5’-

\section{CAGCCAAGCTTGGCACTGGCCGTCGTTCTTACAACGTCGTGTTGTGAC-3'. The DNA} substrate was formed by annealing oligo 2 and ${ }^{32} \mathrm{P} 5$ 'end-labeled oligo 1 at their equimolar concentrations. The duplex formation was verified by native $15 \%$ polyacrylamide (PAA) gel electrophoresis; resulting substrate contained no more than $1 \%$ of single-stranded fraction. Preparation of anthracycline-modified DNA substrates: The stock solutions of DOX a p-DOX were prepared in water and their concentrations were determined by absorption spectrophotometry. Double stranded $5^{\prime}$-end labeled substrate $(1 \mu \mathrm{M})$ was incubated with various concentrations of DOX or p-DOX in 1xPBS, pH 7.4 at $37{ }^{\circ} \mathrm{C}$ for $6 \mathrm{~h}$.

Assay: The helicase assay measures the unwinding of ${ }^{32} \mathrm{P}$-labeled DNA fragment from a duplex DNA molecule. The helicase assay was a modification of previously described methods $[18,19]$. Briefly, helicase assay reactions $(10 \mu \mathrm{L})$ containing $25 \mathrm{mM}$ Tris $(\mathrm{pH} 7.4), 2,5 \mathrm{mM} \mathrm{MgCl} 2,1 \mathrm{mM}$ DTT, $2 \mathrm{mM}$ ATP, $50 \mathrm{mM} \mathrm{KCl}$, bovine serum albumin $\left(0.1 \mathrm{mg} \mathrm{mL}^{-1}\right), 0.1 \mathrm{pmol}$ of ${ }^{32} \mathrm{P}$-labeled helicase substrate (nonmodified or preincubated with DOX or p-DOX) were initiated by the addition of BLM protein $(40 \mathrm{nM})$ and incubated at $37^{\circ} \mathrm{C}$ for $30 \mathrm{~min}$. Reactions were terminated by the addition of $0.3 \% \mathrm{SDS}, 10 \mathrm{mM} \mathrm{Na}_{2} \mathrm{H}_{2}$ edta, $5 \%$ glycerol, and $0.005 \%$ bromphenol blue and the products were resolved on $12 \%$ nondenaturing PAA gel. Helicase activity (unwinding) was 
determined by measuring the percentage of 20 -mer DNA dissociated in $30 \mathrm{~min}$ at $37^{\circ} \mathrm{C}$. The percentage of 20-mer DNA was calculated as the amount of [single-stranded species divided by the total amount of labeled DNA in each lane] $\times 100$, including subtraction of any single-stranded component in the original substrate preparation. The effect of anthracyclines on the unwinding activity of BLM protein was determined using following equation:

$\%$ unwinding efficiency $=(\%$ unwinding of anthracycline - treated substrate $/ \%$ unwinding of control, untreated substrate) x 100. All data represent the average of at least two independent experiments.

2.6. DNA transcription by RNA polymerase in vitro

Transcription of the (NdeI/HpaI) restriction fragment of pSP73KB DNA with T7 RNA polymerase and electrophoretic analysis of transcripts were performed according to the protocols recommended by Promega (Promega Protocols and Applications, 43-46 (1989/90)) and previously described in detail.[20] The concentration of DNA used in this assay was $3.9 \times 10^{-5} \mathrm{M}$ (relative to the monomeric nucleotide content) and the concentration of anthracyclines used to modify DNA before T7 RNA polymerase was added was $3.9 \times 10^{-7} \mathrm{M}(r$ was 0.01$)$. It was verified that preincubation of T7 RNA polymerase with anthracyclines $\left(3.9 \times 10^{-7} \mathrm{M}\right)$ had no effect on its activity.

\subsection{In vitro detection of drug-DNA adducts}


pSP73 DNA (25 $\mu \mathrm{M}$ bp) linearized by EcoRI and $3^{\prime}$-end-labeled by KF and $\left[\alpha-{ }^{32} \mathrm{P}\right] \mathrm{dATP}$ was incubated with DOX or p-DOX $(1 \mu \mathrm{M})$ for $6 \mathrm{~h}$ at $37^{\circ} \mathrm{C}$ at varying $\mathrm{pH}$ values in PBS buffer (137 mM NaCl, $10 \mathrm{mM}$ sodium phosphate, $2.7 \mathrm{mM} \mathrm{KCl,} \mathrm{pH} \mathrm{7.4).} \mathrm{The} \mathrm{DNA} \mathrm{was} \mathrm{then} \mathrm{subjected}$ to phenol/chloroform extraction and ethanol precipitation. The pellet was resuspended in alkaline buffer $\left(0.03 \mathrm{M} \mathrm{NaOH}, 1 \mathrm{mM} \mathrm{Na} \mathrm{H}_{2}\right.$ edta) for $10 \mathrm{~min}$. Samples were loaded onto a $1 \%$ alkaline agarose gel, and DNA was separated electrophoretically in TAE buffer [40 mM Tris-acetate, 1 $\left.\mathrm{mM} \mathrm{Na} \mathrm{H}_{2} \mathrm{edta}(\mathrm{pH} 8.0)\right]$ at $2.5 \mathrm{~V} \mathrm{~cm}^{-1}, 6 \mathrm{~h}, 4^{\circ} \mathrm{C}$.

\subsection{Other physical methods}

Absorption spectra were measured with a Beckmann DU-7400 spectrophotometer. The measurements of fluorescence were performed on a Varian Cary Eclipse spectrofluorophotometer using a $1 \mathrm{~cm}$ quartz cell. The gels were visualized by using a BAS 2500 FUJIFILM bio-imaging analyzer, and the radioactivities associated with bands were quantitated with the AIDA image analyzer software (Raytest, Germany).

\section{Results}

\subsection{Determination of binding constants}

DNA binding constants were determined by fluorescence titration as described previously [17]. Under our experimental conditions, nonlinear least-squares analyses of the binding 
isotherms for the interaction of DOX and p-DOX indicate that the binding affinity of p-DOX with DNA is relatively high but slightly lower than that of DOX (Fig. 3 and Table 1).

\subsection{Viscometry}

A useful technique to investigate intercalation is viscosity measurements, which are sensitive to alterations in DNA length. The effects of DOX and p-DOX on the viscosity of rod-like CT DNA are shown in Fig. 4. On increasing the amounts of DOX and p-DOX, the relative viscosity of DNA increased steadily, although the effect of p-DOX was less pronounced.

\subsection{Inhibition of human topoisomerase II activity in cell-free decatenation assay}

DOX bound to DNA has been identified as an inhibitor of the DNA-decatenating enzyme topoisomerase II (topoII), this being believed to be one of the mechanisms of action of this drug. TopoII cuts both strands of the DNA double helix simultaneously in order to manage DNA tangles and supercoils. Once cut, the ends of the DNA are separated, and a second DNA duplex is passed through the break. Following passage, the cut DNA is re-sealed [21]. DOX is intercalated into DNA at the site of cleavage alongside the topoisomerase protein, resulting in stabilization of the cleavable complex [22]. Stabilization of the cleavable complex is responsible for the stalling of topoII activity [23]. TopoII activity was assessed by the decatenation of kinetoplast DNA [24]. TopoII catalyzes strand-passing of double-stranded kinetoplast DNA yielding several types of decatenated kinetoplast DNA monomers: the supercoiled form, covalently closed circular relaxed 
form, linear DNA, and the nicked open circular form due to pre-existing nicks in the kinetoplast DNA (Fig. 5A).

In the first series of experiments, the experimental conditions were chosen (Fig. 5A) which favor the appearance and detection of linear DNA formed as a consequence of stabilization of topoII cleavage complexes. It has been shown that DOX can act like etoposide by blocking DNA religation in particular at low concentrations [25] and that in the case of DOX, larger amounts of the enzyme are required to detect the cleavage complex in vitro (TopoGen, Port Orange, Florida). As it can be seen in the Fig. 5A, DOX and p-DOX at their relatively lower concentrations and in the presence of a higher concentration of ATP inhibited decatenation of kinetoplast DNA by topoII resulting in the formation of linear DNA; its amount increased with growing level of the modification of kinetoplast DNA by DOX and p-DOX roughly in the same extent or in other words efficiency of the modifications of kinetoplast DNA by both drugs (DOX and p-DOX) to stabilize cleavable complexes was roughly the same.

It has been also shown that DOX, unlike other topoII poisons including other anthracycline drugs, traps only very low levels of topoII cleavage complexes [26-28]. In addition, DOX, in particular at relatively high concentrations, can block the catalytic cycle of topoII also by interfering with topoII binding to DNA (at the beginning of the catalytic cycle of topoII) [25]. Also importantly, it is well established fact that inhibition of topoII catalytic activity without trapping cleavage complexes is observed for DNA intercalators when they alter DNA structure, thereby preventing topoII from binding DNA $[25,29,30]$. Thus, the reason why DOX and p-DOX traps only very low levels of topoII cleavage complexes may be connected with the fact that both drugs considerably change DNA conformation [see section 3.2 (Fig. 4 and Supplemental Information]. 
Therefore, we also performed experiment when reaction mixtures with kinetoplast DNA contained DOX and p-DOX at higher concentrations and the amount of topoII and concentration of ATP was lowered compared with the experiment shown in Fig 5A. It is shown in Fig. 5B that under these experimental conditions inhibition of the topo II catalyzed decatenation of kinetoplast DNA no linear DNA (topoII cleavage complexes) was detected. The results of this experiment apparently also reflect capability of DOX or p-DOX to act by interfering with topoII binding to DNA (at the beginning of the catalytic cycle of topoII). On the other hand, results shown in Fig. 5B convincingly demonstrate that the amount of decatenated kDNA (supercoiled and relaxed DNA) decreased with growing level of the modification of kinetoplast DNA by DOX and p-DOX and disappeared when both drugs were present in the reaction mixture at the approximately identical concentration $(10 \mu \mathrm{M})$. Hence, the efficiency of DOX and p-DOX to inhibit formation of the decatenation products was roughly the same or in other words efficiency of the modifications of kinetoplast DNA by both drugs (DOX and p-DOX) to interfere with topoII binding to DNA was roughly the same.

\subsection{Inhibition of the human Bloom's syndrome helicase activity}

To evaluate the mechanisms of p-DOX and DOX action that may be relevant to the clinical effectiveness of these agents, we tested how DNA modifications by these drugs interfere with DNA strand separation activity of human helicase. The efficiency of BLM helicase to unwind DNA preincubated with various concentrations of DOX and p-DOX was tested by using the standard strand displacement assay as described in the Experimental section. The helicase assay measures the unwinding of ${ }^{32} \mathrm{P}$-labeled 20-nt DNA fragment from a duplex DNA molecule 
containing both $5^{\prime}$ - and $3^{\prime}$-overhanging ends. BML protein showed significant activity if the substrate was untreated - $\sim 70 \%$ of the substrate was unwound (Figs. $6 \mathrm{~A}-\mathrm{C}$, lanes 3 ). If the substrate was pretreated with p-DOX or DOX, DNA strand separation activity of BLM helicase was inhibited. The effect of $\mathrm{p}$-DOX was much more pronounced compared to that of DOX. The $\mathrm{IC}_{50}$ values (defined as concentrations of anthracycline used to modify DNA which inhibits strand separation activity of BLM helicase activity by 50\%) found for DOX and p-DOX were (4.5 \pm 0.1) $\mathrm{x} 10^{-5} \mathrm{M}$ and $(3.0 \pm 0.2) \times 10^{-8} \mathrm{M}$, respectively. Thus, the capability of $\mathrm{p}$-DOX bound to DNA to inhibit DNA strand separation activity of BLM helicase is three orders of magnitude higher than that of parental DOX.

\subsection{Inhibition of transcription activity of prokaryotic T7 RNA polymerase}

Another enzyme whose activity is associated with DNA strand separation is RNA polymerase. In cells, RNA polymerase is needed for constructing RNA chains from DNA genes as templates in a process called DNA transcription. In chemical terms, RNA polymerase is a nucleotidyl transferase that polymerizes ribonucleotides at the 3' end of an RNA transcript. During transcription, the RNA polymerase unwinds a portion of the double-stranded DNA, exposing the DNA template strand that will be copied into RNA. Thus, the agents capable of inhibiting separation of complementary strands in double-helical DNA can efficiently inhibit DNA transcription.

Further investigations were therefore aimed at finding whether DNA lesions formed in natural DNA by DOX and p-DOX can differently inhibit the in vitro RNA synthesis by T7 RNA polymerase on DNA templates modified by these anthracyclines. Cutting of pSP73KB DNA by 
NdeI and HpaI endonucleases yielded a 212-bp fragment containing T7 RNA polymerase promoter [20]. The experiments were carried out using this DNA fragment preincubated with DOX or p-DOX at $r=0.01$ ( $r$ is defined as a drug to nucleotide ratio) for RNA synthesis by T7 RNA polymerase (Fig. 7A, lanes DOX and p-DOX, respectively). RNA synthesis on the DNA template modified by p-DOX yielded a considerable amount of RNA fragments which were shorter than would correspond to a full transcription of the NdeI/HpaI fragment. Strong and medium intensity bands observed for the template modified by p-DOX (Fig. 7A, lane p-DOX) were taken to indicate the sites of preferential binding of p-DOX to DNA. They mostly occurred at the level of sequences containing dG (Fig. 7B). In contrast, RNA synthesis on the same template modified by DOX under exactly identical conditions was not prematurely terminated (Fig. 7A, lane DOX).

\subsection{DNA interstrand cross-links}

DOX forms adducts with DNA and the formaldehyde is involved in their formation [31, 32]. Importantly, previous studies have shown [33] that DOX-DNA adducts formed in the presence of formaldehyde or formaldehyde releasing agents are more cytotoxic lesions than topoII-mediated DNA double strand breaks. It was shown in the previous studies [34] that these adducts exhibit sufficient stability so that they can be detected and quantified in vitro using electrophoretic interstrand crosslinking assays employing mild denaturing conditions. In these experiments described in the previously published work [34] DNA containing DOX-DNA adducts (interstrand CLs formed in the presence of formaldehyde or formaldehyde releasing agents) stabilized the DNA sufficiently to resist denaturation conditions and therefore migrated more slowly as double- 
stranded DNA [34]. On the other hand, DNA that lacked adducts was denatured under the same conditions and migrated as single-stranded nucleic acid [34]. In contrast, p-DOX, which has the daunosamine nitrogen incorporated in a five-membered ring, should be capable of forming an aminal adduct with an amino group of a guanine base in close vicinity to their binding site in absence of formaldehyde. Therefore, we examined in the present work capability of p-DOX to form interstrand CLs using gel electrophoresis under mild denaturing conditions (Fig. 8B). We verified previous observations [5] that DOX formed no interstrand CLs in absence of formaldehyde or formaldehyde releasing agents (Fig. 8A). On the other hand, p-DOX readily formed interstrand CLs in a pH-independent manner (Fig. 8B, lanes 2-7).

\section{Discussion}

DOX is an important anticancer agent, but its clinical use is limited by a dose-limiting cardiotoxicity $[2,35,36]$. A rational design of anthracycline antitumor agents with improved potency requires a mechanistic understanding of how existing anthracyclines achieve their activities. As a result of efforts to design a new, more potent and less cardiotoxic analogue of DOX, a number of new analogues of DOX have been designed and tested [37]. DOX can be modified either at aglycone (carbonyl group, C-14 hydroxyl group) or at daunosamine amino group. The latter modification has been studied most extensively resulting in a number of derivatives exhibiting high cytostatitc activity [38]. Among them, a specific group of exceptionally cytotoxic analogues of DOX possessing intercalating/alkylation activity has 
emerged [39, 40]. p-DOX is a member of this family of DOX analogues [8] and was taken as a representative of this group of anthracyclines for this study.

p-DOX is 500-1000 times more active in human and mouse cancer cells than its parental compound in vitro [8]. The biochemical factors acting on molecular level responsible for so radical difference in potency of DOX and p-DOX are not completely clear. To provide this information, in the present work we investigated in cell-free media by biochemical and biophysical methods interactions of DOX and p-DOX with DNA, effects of DNA modifications by these anthracyclines on activity of human topoisomerase II, human Bloom's syndrome helicase and prokaryotic T7 RNA polymerase and capability of DOX and p-DOX to form interstrand CLs in formaldehyde-free medium.

DOX rapidly enters the nucleus of cells where it binds with high affinity to DNA by classical intercalation between base pairs. We show that the binding affinity of p-DOX with DNA is lower than that of DOX (Fig. 3 and Table 1). This result can be interpreted to mean that favorable interactions associated with DNA binding of DOX, such as hydrophobic interactions, van der Waals, electrostatic interactions, and water contribution are affected by conversion of DOX to p-DOX so that its DNA binding affinity is diminished.

Consistent with this interpretation is also analysis of CT DNA modified by DOX and p-DOX by circular and linear dichroism (CD and LD) spectrometry (Figs. S1 and S2 in the Supplemental Information) and viscometry (Fig. 4). The results of CD studies (Fig. S1 in the Supplemental Information) are consistent with the thesis that both DOX and p-DOX intercalate into doublehelical DNA and that differences exist in the interaction specificities of DOX and p-DOX with DNA. The LD spectra (Fig. S2 in the Supplemental Information) show that both DOX and pDOX bind to DNA in a specific orientation(s), not randomly [41]. Moreover, negative sign of the 
LD signal that arises in the $350-600 \mathrm{~nm}$ region suggests that the angle of the long axis of DOX and p-DOX to the axis of the DNA double helix is more than $54^{\circ}$ as expected for an intercalator [41]. The DNA LD bands (220-300 nm) confirm that the DNA remains in the presence of DOX and $\mathrm{p}$-DOX in the B-DNA conformation, however, some structural changes in DNA are suggested by the increase in the amplitude of DNA negative LD band at $260 \mathrm{~nm}$ upon drug addition (Figs. S2A,B in the Supplemental Information). An increase in the amplitude of the negative $260 \mathrm{~nm}$ LD band of DNA is usually associated with DNA stiffening [41-43] so that the effect of DOX and p-DOX on this DNA LD signal is consistent with an intercalative mode of interaction of both anthracyclines.

Similarly, under appropriate conditions, intercalation of DOX causes a significant increase in viscosity of DNA solution due to the increase in separation of base pairs at intercalation sites and hence results in an increase in overall DNA contour length $[44,45]$. Thus, the observations that p-DOX increases the amplitude of the LD negative $260 \mathrm{~nm}$ band of DNA (Fig. S2 in the Supplemental Information) and the relative viscosity of DNA solution (Fig. 4) less effectively than DOX indicate that capability of the anthracycline to intercalate is reduced by conversion of DOX to p-DOX.

Results of the experiments aimed at understanding properties of double-helical DNA in the presence of DOX and p-DOX (Figs. 3,4, Figs. S1 and S2 in the Supporting Information) revealed only small differences in the effects of these anthracyclines or even showed that more potent pDOX affected properties of DNA less than DOX. Thus, these differences in DNA binding modes of DOX and p-DOX can be hardly correlated with the marked difference in biological effects of these drugs. Therefore, our further studies were focused on the effects of lesions induced in DNA 
by these anthracyclines on activity of several enzymes proposed to inhibit downstream cellular processes which process DNA damaged by anthracyclines.

The enzyme which is most frequently mentioned as an attractive and persuasive component of the mechanism of action of DOX is topoII (see reviews of D.A. Gewirtz [4] and D.A Burden [1] for original references). Hence, we also examined whether there is a difference corresponding to the marked difference in biological effects of DOX and p-DOX in the capability of DNA lesions induced by these drugs to act as topoII inhibitors. DOX acts by stabilizing a reaction intermediate in which DNA strands are cut, eventually impeding DNA resealing $[2,3]$ and/or by blocking the catalytic cycle of topoII by interfering with topoII binding to DNA (at the beginning of the catalytic cycle of topoII) [25]. The results of the present work (Fig. 5) show that the inhibition of topoII may be involved in the exhibition of the antitumor effect of p-DOX as well, but capability of DNA modifications by this drug to inhibit topoII does not significantly differ from that of parental DOX. Hence, inhibition of topoII may only represent an ancillary mechanism of action of p-DOX, which can, however, hardly explain its radically enhanced toxicity in cancer cells.

Several articles (e.g. refs. [9-11, 46]) also report on capability of anthracyclines including DOX to potently block helicases, i.e. the enzymes which are essential for the biochemical processing of double-helical DNA because of their enzymatic action of separating hydrogenbonded complementary strands of double-helical nucleic acids [12]. Thus, these enzymes play important roles in every aspect of DNA processing, including DNA replication, transcription, and repair $[13,14]$, i.e. also in the processes undoubtedly related to biological effects of anthracyclines. Therefore, we also tested the hypothesis that downstream cellular processes which process DNA damaged by DOX or p-DOX and involve separation of complementary 
strands of DNA are inhibited by DNA lesions induced by p-DOX considerably more than by those induced by parental DOX (in the extent corresponding to the marked difference in antiproliferative effects of these anthracyclines observed in vitro [8]). We demonstrate in the present work (Fig. 6) that the ability of DNA modifications by p-DOX to inhibit DNA strand separation activity of BLM helicase is three orders of magnitude higher compared with parental DOX. Intriguingly, this finding nicely correlates with markedly higher antiproliferative activity of p-DOX (500-1000 times) compared to DOX [8]. An important issue that was raised in association with extrapolation of the results of the experiments performed in vitro to the situation in vivo was that several in vitro experiments had been performed at concentrations of DOX (higher than $1 \mu \mathrm{M}$ ) which were considered too high compared with plasma concentrations observed in patients [4]. We find that the $\mathrm{IC}_{50}$ values found for inhibition by p-DOX of DNA strand separation by human BLM helicase is only $3.0 \times 10^{-8} \mathrm{M}$. Hence, also in this context, inhibition of helicases remains an attractive and compelling molecular mechanism explaining the markedly enhanced antitumor effects of p-DOX at clinically relevant concentrations.

Some of the earliest studies describing possible mechanisms of action of DOX relate its biological effects to its capacity to inhibit DNA and RNA synthesis [47-49]. The process of RNA synthesis by DNA-dependent RNA polymerases is also associated with DNA strand separation. We demonstrate in the present work (Fig. 7A) that while modification of template DNA by parental DOX was unable to prematurely terminate RNA synthesis by T7 RNA polymerase, p-DOX was in this respect very efficient. Hence, the plausible explanation of this observation is that similarly as in the case of the inhibition of helicases (vide supra), markedly enhanced capability of lesions induced in DNA by p-DOX to inhibit DNA strand separation (needed to 
expose the DNA template strand to be copied into RNA) is responsible for its markedly enhanced capability to inhibit RNA synthesis.

The results of our in vitro experiments suggest that an important factor responsible for the markedly higher antiproliferative potency of p-DOX compared to parental DOX is capability of the former anthracycline to inhibit downstream cellular processes which process DNA damaged by this drug and involve separation of complementary strands of DNA, such as DNA unwinding by helicases or RNA polymerases and perhaps also by DNA repair proteins.

We demonstrate in this work (Fig. 8) that p-DOX readily forms in double-helical DNA interstrand CLs even in absence of formaldehyde or formaldehyde releasing agents (Fig. 8B) whereas parental DOX does not (Fig. 8A). In general, CLs connecting two complementary strands of double-helical DNA impede separation of complementary strands of DNA. Thus, it seems reasonable to conclude that capability of p-DOX to form interstrand CLs is particularly responsible for cytotoxic processes in cells (treated with this agent) involving inhibition of separation of complementary strands of DNA. The results of the present work suggest that among such processes might be those involving helicases or RNA polymerases, but very likely not those involving topoII.

Taken together, the results of the present work indicate that the blockade of DNA helicases by DNA adducts of p-DOX may be central in the mechanism of action of this anthracycline associated with its markedly enhanced activity as an anticancer drug. Thus, it can be also anticipated that by switching the mechanism of action of DOX by its conversion to p-DOX, not only a reduced concentration of drug is required to achieve similar cell kill as compared to parental DOX, but also resistance to DOX may be overcome [50]. 


\section{Acknowledgements}

This research was supported by the Czech Science Foundation (P301/09/H004). The authors also acknowledge that their participation in the EU COST Action D39 has enabled them to exchange regularly their most recent ideas in the field of anticancer drugs with several European colleagues.

\section{Appendix A. Supplementary data}

Supplementary data associated with this article can be found, in the online version, at doi: ...

\section{References}

[1] Burden DA, Osheroff N. Mechanism of action of eukaryotic topoisomerase II and drugs targeted to the enzyme. Biochim Biophys Acta 1998;1400:139-54.

[2] Minotti G, Menna P, Salvatorelli E, Cairo G, Gianni L. Anthracyclines: Molecular advances and pharmacologic developments in antitumor activity and cardiotoxicity. Pharmacol Rev 2004;56:185-229.

[3] Cutts SM, Nudelman A, Rephaeli A, Phillips DR. The power and potential of doxorubicinDNA adducts. IUBMB Life 2005;57:73-81.

[4] Gewirtz DA. A critical evaluation of the mechanisms of action proposed for the antitumor effects of the anthracycline antibiotics adriamycin and daunorubicin. Biochem Pharmacol 1999;57:727-41. 
[5] Swift LP, Cutts SM, Rephaeli A, Nudelman A, Phillips DR. Activation of adriamycin by the $\mathrm{pH}$-dependent formaldehyde-releasing prodrug hexamethylenetetramine. Mol Cancer Ther 2003;2:189-98.

[6] Taatjes DJ, Fenick DJ, Koch TH. Nuclear targeting and nuclear retention of anthracyclineformaldehyde conjugates implicates DNA covalent bonding in the cytotoxic mechanism of anthracyclines. Chem Res Toxicol 1999;12:588-96.

[7] Post GC, Barthel BL, Burkhart DJ, Hagadorn JR, Koch TH. Doxazolidine, a proposed active metabolite of doxorubicin that cross-links DNA. J Med Chem 2005;48:7648-57.

[8] Nagy A, Aramatis P, Schally AV. High yield conversion of doxorubicin to 2pyrrolinodoxorubicin, an analog 500-1000 times more potent: Structure-activity relationship of daunosamine-modified derivatives of doxorubicin. Proc Natl Acad Sci USA 1996;93:2464-9.

[9] Bachur NR, Lun L, Sun PM, Trubey CM, Elliott EE, Egorin MJ, et al. Anthracycline antibiotic blockade of SV40 T antigen helicase action. Biochem Pharmacol 1998;55:102534.

[10] Tuteja R, Tuteja N, Malhotra P, Singh Chauhan V. Replication fork-stimulated eIF-4A from Plasmodium cynomolgi unwinds DNA in the $3^{\prime}$ to 5 ' direction and is inhibited by DNA-interacting compounds. Arch Biochem Biophys 2003;414:108-14.

[11] Suntornthiticharoen P, Petmitr S, Chavalitshewinkoon-Petmitr P. Purification and characterization of a novel 3 '-5 ' DNA helicase from Plasmodium falciparum and its sensitivity to anthracycline antibiotics. Parasitology 2006;133:389-98.

[12] Matson SW, Kaiserrogers KA. DNA helicases. Annu Rev Biochem 1990;59:289-329. 
[13] Lohman TM, Bjornson KP. Mechanisms of helicase-catalyzed DNA unwinding. Annu Rev Biochem 1996;65:169-214.

[14] Ellis NA. DNA helicases in inherited human disorders. Curr Opin Genet Dev 1997;7:35463.

[15] Brabec V, Palecek E. The influence of salts and $\mathrm{pH}$ on polarographic currents produced by denatured DNA. Biophysik 1970;6:290-300.

[16] Brabec V, Palecek E. Interaction of nucleic acids with electrically charged surfaces. II. Conformational changes in double-helical polynucleotides. Biophys Chem 1976;4:76-92.

[17] Qu XG, Chaires JB. Analysis of drug-DNA binding data. In: Johnson ML, Brand L, editors. Numerical computer methods, Part C, San Diego/CA: Academic Press Inc; 2000, p. 353-69.

[18] Brosh RM, Li JL, Kenny MK, Karow JK, Cooper MP, Kureekattil RP, et al. Replication protein A physically interacts with the Bloom's syndrome protein and stimulates its helicase activity. J Biol Chem 2000;275:23500-8.

[19] Macris MA, Krejci L, Bussen W, Shimamoto A, Sung P. Biochemical characterization of the RECQ4 protein, mutated in Rothmund-Thomson syndrome. DNA Repair 2006;5:17280.

[20] Brabec V, Leng M. DNA interstrand cross-links of trans-diamminedichloroplatinum(II) are preferentially formed between guanine and complementary cytosine residues. Proc Natl Acad Sci USA 1993;90:5345-9.

[21] Berger JM, Gamblin SJ, Harrison SC, Wang JC. Structure and mechanism of DNA topoisomerase II. Nature 1996;379:225-32. 
[22] Moro S, Beretta GL, Dal Ben D, Nitiss J, Palumbo M, Capranico G. Interaction model for anthracycline activity against DNA topoisomerase II Biochemistry 2004;43:7503-13.

[23] Liu LF, Rowe TC, Yang L, Tewey KM, Chen GL. Cleavage of DNA by mammalian DNA topoisomerase II. J Biol Chem 1983;258:15365-70.

[24] Onda T, Toyoda E, Miyazaki O, Seno C, Kagaya S, Okamoto K, et al. NK314, a novel topoisomerase II inhibitor, induces rapid DNA double-strand breaks and exhibits superior antitumor effects against tumors resistant to other topoisomerase II inhibitors. Cancer Lett 2008;259:99-110.

[25] Pommier Y, Leo E, Zhang H, Marchand C. DNA topoisomerases and their poisoning by anticancer and antibacterial drugs. Chem Biol 2010;17:421-33.

[26] Ferrazzi E, Woynarowski JM, Arakali A, Brenner DE, Beerman TA. DNA damage and cytotoxicity induced by metabolites of anthracycline antibiotics, doxorubicin and idarubicin. Cancer Commun 1991;3:173-80.

[27] Capranico G, Supino R, Binaschi M, Capolongo L, Grandi M, Suarato A, et al. Influence of structural modifications at the $3^{\prime}$ and 4' positions of doxorubicin on the drug ability to trap topoisomerase II and to overcome multidrug resistance. Mol. Pharmacol. 199445 908-15

[28] Montaudon D, Pourquier P, Denois F, de Tinguy-Moreaud E, Lagarde P, Robert J. Differential stabilization of topoisomerase-II-DNA cleavable complexes by doxorubicin and etoposide in doxorubicin-resistant rat glioblastoma cells. Eur J Biochem 1997;245:30715.

[29] Pommier Y, Schwartz RE, Kohn KW, Zwelling LA. Formation and rejoining of deoxyribonucleic-acid double-strand breaks induced in isolated cell-nuclei by antineoplastic intercalating agents. Biochemistry 1984;23:3194-201. 
[30] Tewey KM, Chen GL, Nelson EM, Liu LF. Intercalative antitumor drugs interfere with the breakage-reunion reaction of mammalian DNA topoisomerase II. J Biol Chem 1984;259:9182-7.

[31] Taatjes DJ, Gaudiano G, Resing K, Koch TH. Redox pathway leading to the alkylation of DNA by the anthracycline, antitumor drugs adriamycin and daunomycin. J Med Chem 1997;40:1276-86.

[32] Cutts SM, Swift LP, Rephaeli A, Nudelman A, Phillips DR. Sequence specificity of Adriamycin-DNA adducts in human tumor cells. Mol Cancer Therapeutics 2003;2:661-70.

[33] Swift LP, Rephaeli A, Nudelman A, Phillips DR, Cutts SM. Doxorubicin-DNA adducts induce a non-topoisomerase II-mediated form of cell death. Cancer Res 2006;66:4863-71.

[34] Culliane C, van Rosmalen A, Philips DR. Does adriamycin induce interstrand cross-links in DNA? Biochemistry 1994;33:4632-8.

[35] Arola OJ, Saraste A, Pulkki K, Kallajoki M, Parvinen M, Voipio-Pulkki LM. Acute doxorubicin cardiotoxicity involves cardiomyocyte apoptosis. Cancer Res 2000;60:178992.

[36] Wouters KA, Kremer LCM, Miller TL, Herman EH, Lipshultz SE. Protecting against anthracycline-induced myocardial damage: a review of the most promising strategies. $\mathrm{Br} \mathrm{J}$ Haematol 2005;131:561-78.

[37] Lown JW. Anthracycline and anthraquinone anticancer agents: Current status and recent developments. Pharmacol Ther 1993;60:185-214.

[38] Binaschi M, Bigioni M, Cipollone A, Rossi C, Goso C, Maggi CA, et al. Anthracyclines: Selected new developments. Curr Med Chem - Anti-Cancer Agents 2001;1:113-30. 
[39] Cherif A, Farquhar D. N-(5,5-diacetoxypent-1-Y1)doxorubicin: A new intensely potent doxorubicin analog. J Med Chem 1992;35:3208-14.

[40] Sikic BI, Ehsan MN, Harker WG, Friend NF, Brown BW, Newman RA, et al. Dissociation of antitumor potency from anthracycline cardiotoxicity in a doxorubicin analog. Science 1985;228:1544-6.

[41] Rodger A, Marington R, Geeves MA, Hicks M, de Alwis L, Halsall DJ, et al. Looking at long molecules in solution: what happens when they are subjected to Couette flow? Phys Chem Chem Phys 2006;8:3161-71.

[42] Ihara T, Ikegami T, Fujii T, Kitamura Y, Sueda S, Takagi M, et al. Metal ion-directed cooperative DNA binding of small molecules. J Inorg Biochem 2006;100:1744-54.

[43] Chou P-J, Johnson WC. Base inclinations in natural and synthetic DNAs. J Am Chem Soc 1993;115:1205-14.

[44] Suh D, Chaires JB. Criteria for the mode of binding of DNA binding agents. Bioorg Med Chem 1995;3:723-8.

[45] Grueso E, Prado-Gotor R. Thermodynamic and structural study of pyrene-1carboxaldehyde/DNA interactions by molecular spectroscopy: Probing intercalation and binding properties. Chem Phys 2010;373:186-92.

[46] Yu F, Johnson R, Hickey R, Wu Y, Malkas L. Helicase inhibition by anthracycline anticancer agents. Mol Pharmacol 1992;41:993-8.

[47] Meriwether WD, Bachur NR. Inhibition of DNA and RNA metabolism by daunorubicin and adriamycin in L1210 mouse leukemia. Cancer Res 1972;32:1137-42.

[48] Zunino F, Gambetta R, Di Marco A. The inhibition in vitro of DNA polymerase and RNA polymerases by daunomycin and adriamycin. Biochem Pharmacol 1975;24:309-11. 
[49] Momparler RL, Karon M, Siegel SE, Avila F. Effect of adriamycin on DNA, RNA and protein synthesis in cell-free systems and intact cells. Cancer Res 1976;36:2891-5.

[50] Studenovsky M, Ulbrich K, Ibrahimova M, Rihova B. Polymer conjugates of the highly potent cytostatic drug 2-pyrrolinodoxorubicin. Eur J Pharmaceut Sci 2011;42:156-63. 
Table 1. Summary of thermodynamic parameters for DOX and p-DOX binding to calf thymus DNA in BPES buffer

\begin{tabular}{lcc}
\hline drug & $K_{\mathrm{a}} \mathrm{M}^{-1 \mathrm{a}}$ & $\Delta G^{0}{ }_{25} \mathrm{~kJ} \mathrm{~mol}^{-1 \mathrm{~b}}$ \\
\hline DOX & $1.31 \times 10^{5}$ & 29.22 \\
p-DOX & $8.18 \times 10^{4}$ & 28.04
\end{tabular}

${ }^{\text {a }} K_{\mathrm{a}}$ denotes the DNA equilibrium binding constant, with reference to base pairs.

${ }^{\mathrm{b}} \Delta G^{0}{ }_{25}=-R T \ln K_{\mathrm{a}} ; \Delta G^{0}{ }_{25}$ is free energy at $25^{\circ} \mathrm{C}, T$ is the temperature in Kelvin, and $R$ is the universal gas constant $\left(8.314472 \mathrm{~J} \mathrm{~K}^{-1} \mathrm{~mol}^{-1}\right)$. 
Figure Captions

Fig. 1 - Structures of anthracyclines used in the present work.

Fig. 2 - Structure of p-DOX-DNA adducts ("virtual" interstrand cross-links) and chemistry of their formation where complementary DNA strands are in gray.

Fig. 3 - DNA binding isotherms for the interaction of DOX (empty squares) and p-DOX (full triangles) with calf thymus DNA in BPES buffer. The normalized fluorescence response is shown as a function of total DNA concentration. In these titrations, the ligand concentration was kept constant at $1 \mu \mathrm{M}$, while the DNA concentration was varied. Data fitting and determination of binding parameters were carried out using nonlinear least-squares analysis. The solid lines through the data show the best fitting curves.

Fig. 4 - Dependence of relative viscosity of calf thymus DNA on $r$. DNA was incubated with DOX (empty squares) and p-DOX (full triangles) in BPES buffer at $37^{\circ} \mathrm{C}$.

Fig. 5 - Inhibitory effect of DOX and p-DOX on decatenation of kinetoplast DNA (kDNA) by topoisomerase II. The topoII catalytic activity was determined by the decatenation assay. The kinetoplast catenated DNA was incubated with topoII in the presence or absence of DOX or pDOX, and decatenated DNAs were separated by agarose gel electrophoresis. For details, see Section 2.4. A. Kinetoplat DNA ( $8 \mu \mathrm{M}$ in bp) in presence of DOX or p-DOX $(0.12-4 \mu \mathrm{M}), 5 \mathrm{U}$ of human topoII, $3 \mathrm{mM}$ ATP in $20 \mu \mathrm{L}$ of the assay buffer A. Lanes: LN, linear kDNA marker; M, 
decatenated kDNA marker; $\mathrm{C} 1$, control kDNA; C2, kDNA incubated with topoII in the absence of the drug. 5-8, kDNA incubated with 4, 1.2, 0.4, and $0.12 \mu \mathrm{M}$ DOX, respectively; 9-12, kDNA incubated with $4,1.2,0.4$, and $0.12 \mu \mathrm{M}$ p-DOX, respectively; 13 and 14, kDNA incubated with 1000 and $10 \mu \mathrm{M}$ etoposide (VP-16), respectively. B. Kinetoplast DNA (20 $\mu \mathrm{M}$ in bp) in presence of DOX or p-DOX $(0.3-10 \mu \mathrm{M}), 1.5 \mathrm{U}$ of human topoII, $0.5 \mathrm{mM}$ ATP in $20 \mu \mathrm{L}$ of the assay buffer B. Lanes: LN, linear kDNA marker; M, decatenated kDNA marker; C1, control kDNA; C2, kDNA incubated with topoII in absence of the drug. 5-8, kDNA incubated with 10, 3, 1, and $0.3 \mu \mathrm{M}$ DOX, respectively; 9-12, kDNA incubated with 10,3, 1, and $0.3 \mu \mathrm{M}$ p-DOX, respectively.

Fig. 6 - Effect of DNA modifications by DOX and p-DOX on DNA-unwinding activity of BLM helicase. The helicase reaction was performed as described in Materials and Methods. The structure of the DNA substrate is shown on the left side of each autoradiogram. Asterisk denotes the ${ }^{32}$ P-labeled end. A, B, and C: Autoradiograms of 12\% PAA native gels. Lanes 1: heatdenatured substrate; lanes 2: the substrate incubated without enzyme; lanes 3: reaction with enzyme and without any compound (Control). Lanes 3 - 10 in panels A, B and lanes 3 - 11 in panel C: the reactions with enzyme in the presence of different concentration of compounds used to modify DNA is indicated on the top of each panel. D. Quantitative evaluation of unwinding experiments. The unwinding efficiencies of BML in the presence of DOX (squares) and p-DOX (triangles) were quantified as described in the section Materials and Methods and plotted as a function of drug concentration. Values obtained after incubation of substrate without BLM were $<1 \%$ of the input radioactivity and were subtracted as background. 
Fig. 7 - Inhibition of RNA synthesis by T7 RNA polymerase on the NdeI/HpaI fragment of pSP73KB plasmid modified by DOX and p-DOX. A. Autoradiogram of a 8\% PAA/8M urea sequencing gel showing the inhibition of RNA synthesis by T7 RNA polymerase on the $\mathrm{NdeI} / \mathrm{HpaI}$ fragment modified by DOX or p-DOX at $r=0.01$. Lanes: control, template in absence of anthracycline; A, U, G and C, chain terminated marker DNAs; Dox and p-Dox, the template in the presence of DOX or p-DOX, respectively. B. Schematic diagram showing the portion of the nucleotide sequence used to monitor the inhibition of the RNA synthesis by DOX and p-DOX. The arrow indicates the start of the T7 RNA polymerase, which used the upper strand of the NdeI/HpaI fragment of pSP73KB as template. The short lines above the sequence represent major stop signals for DNA modified by p-DOX. The numbers correspond to the nucleotide numbering in the sequence map of the pSP73KB plasmid.

Fig. 8 - Linearized pSP73 DNA (25 $\mu \mathrm{M}$ in bp) was incubated with DOX (A) or p-DOX (B) $(1 \mu \mathrm{M})$ at various $\mathrm{pH}$ (its value is indicated above each lane). The DNA was then subjected to a cleanup procedure and the pellet was resuspended in $0.03 \mathrm{M} \mathrm{NaOH}, 1 \mathrm{mM} \mathrm{Na} \mathrm{H}_{2}$ edta for 10 min. Subsequently, samples were loaded onto a $1 \%$ agarose gel, and DNA was separated electrophoretically in TAE buffer [40 mM Tris-acetate, $1 \mathrm{mM} \mathrm{Na}_{2} \mathrm{H}_{2} \mathrm{edta}(\mathrm{pH}$ 8.0)]. Lanes: 1 (C1), pSP73 DNA incubated in the absence of the drug at pH 5.8; 2-7, pSP73 DNA incubated in the presence of the drug at $\mathrm{pH}$ indicated above each lane. dsDNA, double-stranded (interstrand crosslinked) DNA; ssDNA, single-stranded DNA. 
Jana Stepankova ${ }^{a}$, Martin Studenovsky ${ }^{b}$, Jaroslav Malina ${ }^{a}$, Jana Kasparkova ${ }^{c}$, Barbora Liskova ${ }^{a}$, Olga Novakova ${ }^{a}$, Karel Ulbrich ${ }^{\mathrm{b}}$, Viktor Brabec ${ }^{\mathrm{a}, *}$

${ }^{a}$ Institute of Biophysics, Academy of Science of the Czech Republic, Kralovopolska 135, CZ61265 Brno, Czech Republic

${ }^{b}$ Institute of Macromolecular Chemistry, Academy of Science of the Czech Republic, Heyrovsky square 2, CZ-16206, Prague 6, Czech Republic

${ }^{c}$ Department of Biophysics, Faculty of Sciences, Palacky University, CZ-77146 Olomouc, Czech Republic

Classification: (1) Antibiotics and Chemotherapeutics

\footnotetext{
* Corresponding author at: Institute of Biophysics, Academy of Sciences of the Czech Republic, v.v.i., Kralovopolska 135, CZ-61265 Brno, Czech Republic. Tel.: +420-541517148; fax: $+420-541240499$.
}

E-mail address: brabec@ibp.cz (V. Brabec) 


\begin{abstract}
It was shown earlier that 2-pyrrolinodoxorubicin was 500-1000 times more active towards human and mouse cancer cells in vitro than parental doxorubicin. However, the biochemical factors responsible for such a large difference in potency between doxorubicin and 2-pyrrolinodoxorubicin are not clear at the molecular level. To provide this information, we have investigated in cell-free media by biochemical and biophysical methods interactions of both anthracyclines with DNA, effects of these interactions on activity of human topoisomerase II, human Bloom's syndrome helicase and prokaryotic T7 RNA polymerase, and the capability of these drugs to form DNA interstrand cross-links in formaldehyde-free medium. Experiments aimed at understanding the properties of double-helical DNA in the presence of doxorubicin and 2-pyrrolinodoxorubicin revealed only small differences in DNA modifications by these anthracyclines and resulting conformational alterations in DNA. Similarly, the ability of 2-pyrrolinodoxorubicin modifications of DNA to inhibit catalytic activity of topoisomerase II does not differ significantly from that of doxorubicin. On the other hand, we demonstrate that an important factor responsible for the markedly higher antiproliferative potency of DNA modifications by 2-pyrrolinodoxorubicin is capability of these modifications to inhibit downstream cellular processes which process DNA damaged by this drug and involve separation of complementary strands of DNA, such as DNA unwinding by helicases or RNA polymerases. In addition, the results are also consistent with the hypothesis that in particular the capability of 2-pyrrolinodoxorubicin to readily form DNA interstrand cross-links is responsible for inhibition of these processes in the cells treated with this analogue of doxorubicin.
\end{abstract}

Keywords: doxorubicin; 2-pyrrolinodoxorubicin; DNA; topoisomerase II; helicase; interstrand 
cross-links 


\section{Introduction}

Doxorubicin (DOX, trade name Adriamycin) or hydroxyldaunorubicin (Fig. 1A), anthracycline antibiotic, is a widely used antitumor drug, which is used for the clinical treatment of a broad range of human malignancies. As far as the mechanism of biological activity is concerned, DOX rapidly enters the nucleus of cells and binds with high affinity to DNA by noncovalent intercalation between base pairs leading to inhibition of synthesis of biomacromolecules. It is generally accepted that biological effects of DOX are associated with its ability to act as a topoisomerase II (topoII) poison perturbing the religation step of this enzyme and forming the ternary DOX-DNA-topoII cleavable complex [1, 2]. In addition, biological effects of DOX have been also related to its capability to form DNA adducts, namely "virtual" interstrand cross-links (CLs) when their formation is mediated by formaldehyde [3]. Not least, generation of free radicals, leading to DNA damage or lipid peroxidation remains a further mechanism to explain the antitumor activity of DOX, although the unresolved question is whether free radicals are generated at clinically relevant concentrations of the anthracyclines and at hypoxic oxygen tension in the tumor cell [4].

The clinical use of DOX is, however, limited by severe side effects such as cardiotoxicity, myelosuppression, and development of multidrug resistance. Such limitations have led researchers to search for alternative or even more active anthracycline. One strategy for improving the efficacy of DOX has been based on the observation that formaldehyde mediates the formation of DOX-DNA adducts or interstrand CLs. In these lesions DOX is linked to one strand of DNA by a single covalent bond and to the complementary strand via an additional hydrogen bond. These discoveries were impetus for coadministration of DOX with 
formaldehyde-releasing prodrugs, such as hexamethylenetetramine [5] and for the syntheses of the DOX-formaldehyde conjugates as drug candidates that carry their own formaldehyde $[6,7]$.

If DOX forms the adduct or interstrand CL it must react with formaldehyde to form an activated Schiff base which is then able to form an aminal (N-C-N) linkage to the exocyclic amino group of guanine residues. Thus, the formaldehyde-conjugated complex is the active form of the drug. The mono-adducts form primarily at $\mathrm{G}$ of $5^{\prime}-\mathrm{GCN}-3^{\prime}$ sequences ( $\mathrm{N}$ is any base) where the chromophore of DOX is intercalated between the $\mathrm{C}$ and $\mathrm{N}$ base pair. In addition, DOX intercalation, covalent bonding, and hydrogen bonding at the C9 hydroxyl combine to form a DNA interstrand CL. Based on this knowledge, a class of more potent, non-crossresistant analogs of DOX with lower cardiotoxicity was developed capable of forming an aminal adduct with an amino group of a guanine base in close vicinity to their binding site (Fig. 2). An example is 2pyrrolinodoxorubicin (p-DOX) (Fig. 1B), which has the daunosamine nitrogen incorporated in a five-membered ring. This analog of DOX proved to be 500-1000 times more active in human and mouse cancer cells than its parental compound in vitro [8].

No information is available about factors involved in the molecular mechanism underlying biological effects of p-DOX responsible for so marked enhancement of its activity compared to DOX. DNA was identified as a major target of DOX and its analogs. Therefore, first we were interested to determine whether there is a difference in DNA binding modes of DOX and p-DOX that would correspond to the marked difference in their biological effects. In addition, topoII is most frequently considered one of the primary target sites for the activity of the anthracycline antibiotics [4]. Hence, we also examined whether there is a difference corresponding to the marked difference in biological effects of DOX and p-DOX in their capability upon DNA binding to act as topoII inhibitors. Finally, several articles (e.g. refs. [2, 9-11]) also report on 


\section{Materials and methods}

\subsection{Chemicals}

Doxorubicin hydrochloride was obtained from Sigma (Prague, Czech Republic) (purity was $\geq 99.9 \%$ based on elemental trace analysis) and was used without further purification. p-DOX was prepared in the same way as described previously [8] and characterized by MALDI-TOF spectroscopy (Bruker Daltonik, Germany) [calcd. 595, found $595.98(\mathrm{M}+\mathrm{H})$ ]. The concentrations of DOX and p-DOX were determined by measuring their visible absorption and using the molar extinction coefficient $\varepsilon_{480 \mathrm{~mm}}=11500 \mathrm{~cm}^{-1} \mathrm{M}^{-1}$. Calf thymus (CT) DNA ( $42 \% \mathrm{G}+\mathrm{C}$, mean molecular mass ca. $20000 \mathrm{kDa}$ ) was prepared and characterized as described previously [15, 16]. 


\subsection{Determination of binding constants}

DNA binding constants were determined by fluorescence titration as described previously [17]. Samples were excited at $480 \mathrm{~nm}$ and emission was measured at $590 \mathrm{~nm}$. The following titrations were carried out. Fixed ligand concentration $(1 \mu \mathrm{M})$ was titrated by increasing CT DNA concentration in BPES buffer $\left(6 \mathrm{mM} \mathrm{Na}_{2} \mathrm{HPO}_{4}, 2 \mathrm{mM} \mathrm{NaH}_{2} \mathrm{PO}_{4}, 1 \mathrm{mM} \mathrm{Na} \mathrm{H}_{2}\right.$ edta, $185 \mathrm{mM}$ $\mathrm{NaCl}, \mathrm{pH}$ 7.4). In the present work the samples of DNA were upon addition of DOX or p-DOX incubated for at least $6 \mathrm{~h}$ at $37^{\circ} \mathrm{C}$ if not stated otherwise. Titration data were fit directly by nonlinear least-squares methods to get binding constants. The titration data were fitted by nonlinear regression (GraphPad Prism) to sigmoidal dose-response to get apparent equilibrium association constants.

\subsection{Viscometry}




\subsection{Topoisomerase II activity assay}

Topoisomerase II (topoII) enzyme activity was assessed by measuring the decatenation of kinetoplast DNA using the Topoisomerase II Assay Kit (TopoGen, Port Orange, Florida). Kinetoplast DNA $(0.2 \mathrm{mM})$ was preincubated with DOX or p-DOX in phosphate buffered saline (PBS) buffer, $\mathrm{pH} 7.4$ at $37{ }^{\circ} \mathrm{C}$ for $6 \mathrm{~h}$. The decatenation assays were performed in reaction mixtures $(20 \mu \mathrm{L})$ containing buffer A (30 mM Tris- $\mathrm{HCl}, \mathrm{pH}$ 7.6, $15 \mathrm{mM}$ 2-mercaptoethanol, 8 $\mathrm{mM} \mathrm{MgCl} 2,60 \mathrm{mM} \mathrm{NaCl}$ ) and $3 \mathrm{mM} \mathrm{ATP}, 5 \mathrm{U}$ of topoII and $8 \mu \mathrm{M}$ catenated kinetoplast DNA preincubated with DOX or p-DOX; or buffer B (containing $50 \mathrm{mM}$ Tris- $\mathrm{HCl}(\mathrm{pH} 8.0), 120 \mathrm{mM}$ $\mathrm{KCl}, 10 \mathrm{mM} \mathrm{MgCl}$, bovine serum albumin $\left(30 \mu \mathrm{g} \mathrm{mL}^{-1}\right), 0.5 \mathrm{mM}$ dithiothreitol $)$ and $0.5 \mathrm{mM}$ ATP, $1.5 \mathrm{U}$ of topoII and $20 \mu \mathrm{M}$ catenated kinetoplast DNA preincubated with DOX or p-DOX. After 30 min of incubation at $37^{\circ} \mathrm{C}$, the reaction was terminated with $2 \mu 1$ of $10 \%$ sodium dodecyl sulfate, followed by proteinase $\mathrm{K}$ treatment $(0.3 \mathrm{mg} / \mathrm{mL})$, and fenol/chloroform extraction and separated in $1 \%$ agarose gel at $4 \mathrm{~V} \mathrm{~cm}^{-1}$, room temperature; the gel contained $\mathrm{EtBr}$ $\left(0.5 \mu \mathrm{g} \mathrm{mL}^{-1}\right)$ and was submerged in TAE buffer. The reaction products were visualized under ultraviolet light and photographed. It was verified that preincubation of topoII with anthracyclines $(3 \mu \mathrm{M})$ had no effect on its activity. 


\subsection{DNA helicase activity assay}

Substrate and protein preparations: Bloom's syndrome helicase (BLM protein) was a kind gift of Dr. Lumir Krejci (Masaryk University, Brno, Czech Republic). The synthetic oligodeoxyribonucleotides used for the preparation of DNA substrates were purchased from VBC-Genomics (Vienna, Austria). The nucleotide sequences used in this study were as follows: Oligo1: 5'- TAAGAACGACGGCCAGTGCC-3', oligo2: 5’-

CAGCCAAGCTTGGCACTGGCCGTCGTTCTTACAACGTCGTGTTGTGAC-3'. The DNA substrate was formed by annealing oligo 2 and ${ }^{32} \mathrm{P} 5$ 'end-labeled oligol at their equimolar concentrations. The duplex formation was verified by native $15 \%$ polyacrylamide (PAA) gel electrophoresis; resulting substrate contained no more than $1 \%$ of single-stranded fraction. Preparation of anthracycline-modified DNA substrates: The stock solutions of DOX a p-DOX were prepared in water and their concentrations were determined by absorption spectrophotometry. Double stranded $5^{\prime}$-end labeled substrate $(1 \mu \mathrm{M})$ was incubated with various concentrations of DOX or p-DOX in 1xPBS, pH 7.4 at $37{ }^{\circ} \mathrm{C}$ for $6 \mathrm{~h}$.

Assay: The helicase assay measures the unwinding of ${ }^{32} \mathrm{P}$-labeled DNA fragment from a duplex DNA molecule. The helicase assay was a modification of previously described methods [18, 19]. Briefly, helicase assay reactions $(10 \mu \mathrm{L})$ containing $25 \mathrm{mM}$ Tris $(\mathrm{pH} 7.4), 2,5 \mathrm{mM} \mathrm{MgCl}, 1 \mathrm{mM}$ DTT, $2 \mathrm{mM}$ ATP, $50 \mathrm{mM} \mathrm{KCl}$, bovine serum albumin $\left(0.1 \mathrm{mg} \mathrm{mL}^{-1}\right), 0.1 \mathrm{pmol}$ of ${ }^{32} \mathrm{P}$-labeled helicase substrate (nonmodified or preincubated with DOX or p-DOX) were initiated by the addition of BLM protein $(40 \mathrm{nM})$ and incubated at $37^{\circ} \mathrm{C}$ for $30 \mathrm{~min}$. Reactions were terminated by the addition of $0.3 \% \mathrm{SDS}, 10 \mathrm{mM} \mathrm{Na}_{2} \mathrm{H}_{2} \mathrm{edta}, 5 \%$ glycerol, and $0.005 \%$ bromphenol blue and the products were resolved on $12 \%$ nondenaturing PAA gel. Helicase activity (unwinding) was 


\subsection{DNA transcription by RNA polymerase in vitro}

Transcription of the (NdeI/HpaI) restriction fragment of pSP73KB DNA with T7 RNA polymerase and electrophoretic analysis of transcripts were performed according to the protocols recommended by Promega (Promega Protocols and Applications, 43-46 (1989/90)) and previously described in detail.[20] The concentration of DNA used in this assay was $3.9 \times 10^{-5} \mathrm{M}$ (relative to the monomeric nucleotide content) and the concentration of anthracyclines used to modify DNA before T7 RNA polymerase was added was $3.9 \times 10^{-7} \mathrm{M}(r$ was 0.01$)$. It was verified that preincubation of T7 RNA polymerase with anthracyclines $\left(3.9 \times 10^{-7} \mathrm{M}\right)$ had no effect on its activity.

\subsection{In vitro detection of drug-DNA adducts}


pSP73 DNA ( $25 \mu \mathrm{M}$ bp) linearized by EcoRI and 3'-end-labeled by KF and $\left[\alpha^{32} \mathrm{P}\right] \mathrm{dATP}$ was incubated with DOX or p-DOX $(1 \mu \mathrm{M})$ for $6 \mathrm{~h}$ at $37^{\circ} \mathrm{C}$ at varying $\mathrm{pH}$ values in PBS buffer (137 mM NaCl, $10 \mathrm{mM}$ sodium phosphate, $2.7 \mathrm{mM} \mathrm{KCl,} \mathrm{pH} \mathrm{7.4).} \mathrm{The} \mathrm{DNA} \mathrm{was} \mathrm{then} \mathrm{subjected}$ to phenol/chloroform extraction and ethanol precipitation. The pellet was resuspended in alkaline buffer $\left(0.03 \mathrm{M} \mathrm{NaOH}, 1 \mathrm{mM} \mathrm{Na} \mathrm{H}_{2}\right.$ edta) for $10 \mathrm{~min}$. Samples were loaded onto a $1 \%$ alkaline agarose gel, and DNA was separated electrophoretically in TAE buffer [40 mM Tris-acetate, 1 $\left.\mathrm{mM} \mathrm{Na}_{2} \mathrm{H}_{2} \mathrm{edta}(\mathrm{pH} 8.0)\right]$ at $2.5 \mathrm{~V} \mathrm{~cm}^{-1}, 6 \mathrm{~h}, 4{ }^{\circ} \mathrm{C}$.

\subsection{Other physical methods}

Absorption spectra were measured with a Beckmann DU-7400 spectrophotometer. The measurements of fluorescence were performed on a Varian Cary Eclipse spectrofluorophotometer using a $1 \mathrm{~cm}$ quartz cell. The gels were visualized by using a BAS 2500 FUJIFILM bio-imaging analyzer, and the radioactivities associated with bands were quantitated with the AIDA image analyzer software (Raytest, Germany).

\section{Results}

\subsection{Determination of binding constants}

DNA binding constants were determined by fluorescence titration as described previously [17]. Under our experimental conditions, nonlinear least-squares analyses of the binding 
isotherms for the interaction of DOX and p-DOX indicate that the binding affinity of p-DOX with DNA is relatively high but slightly lower than that of DOX (Fig. 3 and Table 1).

\subsection{Viscometry}

A useful technique to investigate intercalation is viscosity measurements, which are sensitive to alterations in DNA length. The effects of DOX and p-DOX on the viscosity of rod-like CT DNA are shown in Fig. 4. On increasing the amounts of DOX and p-DOX, the relative viscosity of DNA increased steadily, although the effect of p-DOX was less pronounced.

\subsection{Inhibition of human topoisomerase II activity in cell-free decatenation assay}

DOX bound to DNA has been identified as an inhibitor of the DNA-decatenating enzyme topoisomerase II (topoII), this being believed to be one of the mechanisms of action of this drug. TopoII cuts both strands of the DNA double helix simultaneously in order to manage DNA tangles and supercoils. Once cut, the ends of the DNA are separated, and a second DNA duplex is passed through the break. Following passage, the cut DNA is re-sealed [21]. DOX is intercalated into DNA at the site of cleavage alongside the topoisomerase protein, resulting in stabilization of the cleavable complex [22]. Stabilization of the cleavable complex is responsible for the stalling of topoII activity [23]. TopoII activity was assessed by the decatenation of kinetoplast DNA [24]. TopoII catalyzes strand-passing of double-stranded kinetoplast DNA yielding several types of decatenated kinetoplast DNA monomers: the supercoiled form, covalently closed circular relaxed 
form, linear DNA, and the nicked open circular form due to pre-existing nicks in the kinetoplast DNA (Fig. 5A).

In the first series of experiments, the experimental conditions were chosen (Fig. 5A) which favor the appearance and detection of linear DNA formed as a consequence of stabilization of topoII cleavage complexes. It has been shown that DOX can act like etoposide by blocking DNA religation in particular at low concentrations [25] and that in the case of DOX, larger amounts of the enzyme are required to detect the cleavage complex in vitro (TopoGen, Port Orange, Florida). As it can be seen in the Fig. 5A, DOX and p-DOX at their relatively lower concentrations and in the presence of a higher concentration of ATP inhibited decatenation of kinetoplast DNA by topoII resulting in the formation of linear DNA; its amount increased with growing level of the modification of kinetoplast DNA by DOX and p-DOX roughly in the same extent or in other words efficiency of the modifications of kinetoplast DNA by both drugs (DOX and p-DOX) to stabilize cleavable complexes was roughly the same.

It has been also shown that DOX, unlike other topoII poisons including other anthracycline drugs, traps only very low levels of topoII cleavage complexes [26-28]. In addition, DOX, in particular at relatively high concentrations, can block the catalytic cycle of topoII also by interfering with topoII binding to DNA (at the beginning of the catalytic cycle of topoII) [25]. Also importantly, it is well established fact that inhibition of topoII catalytic activity without trapping cleavage complexes is observed for DNA intercalators when they alter DNA structure, thereby preventing topoII from binding DNA $[25,29,30]$. Thus, the reason why DOX and p-DOX traps only very low levels of topoII cleavage complexes may be connected with the fact that both drugs considerably change DNA conformation [see section 3.2 (Fig. 4 and Supplemental Information]. 


\subsection{Inhibition of the human Bloom's syndrome helicase activity}

To evaluate the mechanisms of p-DOX and DOX action that may be relevant to the clinical effectiveness of these agents, we tested how DNA modifications by these drugs interfere with DNA strand separation activity of human helicase. The efficiency of BLM helicase to unwind DNA preincubated with various concentrations of DOX and p-DOX was tested by using the standard strand displacement assay as described in the Experimental section. The helicase assay measures the unwinding of ${ }^{32} \mathrm{P}$-labeled 20-nt DNA fragment from a duplex DNA molecule 


\subsection{Inhibition of transcription activity of prokaryotic T7 RNA polymerase}

Another enzyme whose activity is associated with DNA strand separation is RNA polymerase. In cells, RNA polymerase is needed for constructing RNA chains from DNA genes as templates in a process called DNA transcription. In chemical terms, RNA polymerase is a nucleotidyl transferase that polymerizes ribonucleotides at the 3' end of an RNA transcript. During transcription, the RNA polymerase unwinds a portion of the double-stranded DNA, exposing the DNA template strand that will be copied into RNA. Thus, the agents capable of inhibiting separation of complementary strands in double-helical DNA can efficiently inhibit DNA transcription.

Further investigations were therefore aimed at finding whether DNA lesions formed in natural DNA by DOX and p-DOX can differently inhibit the in vitro RNA synthesis by T7 RNA polymerase on DNA templates modified by these anthracyclines. Cutting of pSP73KB DNA by 


\subsection{DNA interstrand cross-links}

DOX forms adducts with DNA and the formaldehyde is involved in their formation [31, 32]. Importantly, previous studies have shown [33] that DOX-DNA adducts formed in the presence of formaldehyde or formaldehyde releasing agents are more cytotoxic lesions than topoII-mediated DNA double strand breaks. It was shown in the previous studies [34] that these adducts exhibit sufficient stability so that they can be detected and quantified in vitro using electrophoretic interstrand crosslinking assays employing mild denaturing conditions. In these experiments described in the previously published work [34] DNA containing DOX-DNA adducts (interstrand CLs formed in the presence of formaldehyde or formaldehyde releasing agents) stabilized the DNA sufficiently to resist denaturation conditions and therefore migrated more slowly as double- 


\section{Discussion}

DOX is an important anticancer agent, but its clinical use is limited by a dose-limiting cardiotoxicity $[2,35,36]$. A rational design of anthracycline antitumor agents with improved potency requires a mechanistic understanding of how existing anthracyclines achieve their activities. As a result of efforts to design a new, more potent and less cardiotoxic analogue of DOX, a number of new analogues of DOX have been designed and tested [37]. DOX can be modified either at aglycone (carbonyl group, C-14 hydroxyl group) or at daunosamine amino group. The latter modification has been studied most extensively resulting in a number of derivatives exhibiting high cytostatitc activity [38]. Among them, a specific group of exceptionally cytotoxic analogues of DOX possessing intercalating/alkylation activity has 
emerged [39, 40]. p-DOX is a member of this family of DOX analogues [8] and was taken as a representative of this group of anthracyclines for this study.

p-DOX is 500-1000 times more active in human and mouse cancer cells than its parental compound in vitro [8]. The biochemical factors acting on molecular level responsible for so radical difference in potency of DOX and p-DOX are not completely clear. To provide this information, in the present work we investigated in cell-free media by biochemical and biophysical methods interactions of DOX and p-DOX with DNA, effects of DNA modifications by these anthracyclines on activity of human topoisomerase II, human Bloom's syndrome helicase and prokaryotic T7 RNA polymerase and capability of DOX and p-DOX to form interstrand CLs in formaldehyde-free medium.

DOX rapidly enters the nucleus of cells where it binds with high affinity to DNA by classical intercalation between base pairs. We show that the binding affinity of p-DOX with DNA is lower than that of DOX (Fig. 3 and Table 1). This result can be interpreted to mean that favorable interactions associated with DNA binding of DOX, such as hydrophobic interactions, van der Waals, electrostatic interactions, and water contribution are affected by conversion of DOX to p-DOX so that its DNA binding affinity is diminished.

Consistent with this interpretation is also analysis of CT DNA modified by DOX and p-DOX by circular and linear dichroism (CD and LD) spectrometry (Figs. S1 and S2 in the Supplemental Information) and viscometry (Fig. 4). The results of CD studies (Fig. S1 in the Supplemental Information) are consistent with the thesis that both DOX and p-DOX intercalate into doublehelical DNA and that differences exist in the interaction specificities of DOX and p-DOX with DNA. The LD spectra (Fig. S2 in the Supplemental Information) show that both DOX and pDOX bind to DNA in a specific orientation(s), not randomly [41]. Moreover, negative sign of the 
LD signal that arises in the $350-600 \mathrm{~nm}$ region suggests that the angle of the long axis of DOX and p-DOX to the axis of the DNA double helix is more than $54^{\circ}$ as expected for an intercalator [41]. The DNA LD bands (220-300 nm) confirm that the DNA remains in the presence of DOX and p-DOX in the B-DNA conformation, however, some structural changes in DNA are suggested by the increase in the amplitude of DNA negative LD band at $260 \mathrm{~nm}$ upon drug addition (Figs. S2A,B in the Supplemental Information). An increase in the amplitude of the negative $260 \mathrm{~nm}$ LD band of DNA is usually associated with DNA stiffening [41-43] so that the effect of DOX and p-DOX on this DNA LD signal is consistent with an intercalative mode of interaction of both anthracyclines.

Similarly, under appropriate conditions, intercalation of DOX causes a significant increase in viscosity of DNA solution due to the increase in separation of base pairs at intercalation sites and hence results in an increase in overall DNA contour length [44, 45]. Thus, the observations that p-DOX increases the amplitude of the LD negative $260 \mathrm{~nm}$ band of DNA (Fig. S2 in the Supplemental Information) and the relative viscosity of DNA solution (Fig. 4) less effectively than DOX indicate that capability of the anthracycline to intercalate is reduced by conversion of DOX to p-DOX.

Results of the experiments aimed at understanding properties of double-helical DNA in the presence of DOX and p-DOX (Figs. 3,4, Figs. S1 and S2 in the Supporting Information) revealed only small differences in the effects of these anthracyclines or even showed that more potent pDOX affected properties of DNA less than DOX. Thus, these differences in DNA binding modes of DOX and p-DOX can be hardly correlated with the marked difference in biological effects of these drugs. Therefore, our further studies were focused on the effects of lesions induced in DNA 
by these anthracyclines on activity of several enzymes proposed to inhibit downstream cellular processes which process DNA damaged by anthracyclines.

The enzyme which is most frequently mentioned as an attractive and persuasive component of the mechanism of action of DOX is topoII (see reviews of D.A. Gewirtz [4] and D.A Burden [1] for original references). Hence, we also examined whether there is a difference corresponding to the marked difference in biological effects of DOX and p-DOX in the capability of DNA lesions induced by these drugs to act as topoII inhibitors. DOX acts by stabilizing a reaction intermediate in which DNA strands are cut, eventually impeding DNA resealing $[2,3]$ and/or by blocking the catalytic cycle of topoII by interfering with topoII binding to DNA (at the beginning of the catalytic cycle of topoII) [25]. The results of the present work (Fig. 5) show that the inhibition of topoII may be involved in the exhibition of the antitumor effect of p-DOX as well, but capability of DNA modifications by this drug to inhibit topoII does not significantly differ from that of parental DOX. Hence, inhibition of topoII may only represent an ancillary mechanism of action of p-DOX, which can, however, hardly explain its radically enhanced toxicity in cancer cells.

Several articles (e.g. refs. [9-11, 46]) also report on capability of anthracyclines including DOX to potently block helicases, i.e. the enzymes which are essential for the biochemical processing of double-helical DNA because of their enzymatic action of separating hydrogenbonded complementary strands of double-helical nucleic acids [12]. Thus, these enzymes play important roles in every aspect of DNA processing, including DNA replication, transcription, and repair $[13,14]$, i.e. also in the processes undoubtedly related to biological effects of anthracyclines. Therefore, we also tested the hypothesis that downstream cellular processes which process DNA damaged by DOX or p-DOX and involve separation of complementary 
strands of DNA are inhibited by DNA lesions induced by p-DOX considerably more than by those induced by parental DOX (in the extent corresponding to the marked difference in antiproliferative effects of these anthracyclines observed in vitro [8]). We demonstrate in the present work (Fig. 6) that the ability of DNA modifications by p-DOX to inhibit DNA strand separation activity of BLM helicase is three orders of magnitude higher compared with parental DOX. Intriguingly, this finding nicely correlates with markedly higher antiproliferative activity of p-DOX (500-1000 times) compared to DOX [8]. An important issue that was raised in association with extrapolation of the results of the experiments performed in vitro to the situation in vivo was that several in vitro experiments had been performed at concentrations of DOX (higher than $1 \mu \mathrm{M}$ ) which were considered too high compared with plasma concentrations observed in patients [4]. We find that the $\mathrm{IC}_{50}$ values found for inhibition by p-DOX of DNA strand separation by human BLM helicase is only $3.0 \times 10^{-8} \mathrm{M}$. Hence, also in this context, inhibition of helicases remains an attractive and compelling molecular mechanism explaining the markedly enhanced antitumor effects of p-DOX at clinically relevant concentrations.

Some of the earliest studies describing possible mechanisms of action of DOX relate its biological effects to its capacity to inhibit DNA and RNA synthesis [47-49]. The process of RNA synthesis by DNA-dependent RNA polymerases is also associated with DNA strand separation. We demonstrate in the present work (Fig. 7A) that while modification of template DNA by parental DOX was unable to prematurely terminate RNA synthesis by T7 RNA polymerase, p-DOX was in this respect very efficient. Hence, the plausible explanation of this observation is that similarly as in the case of the inhibition of helicases (vide supra), markedly enhanced capability of lesions induced in DNA by p-DOX to inhibit DNA strand separation (needed to 
expose the DNA template strand to be copied into RNA) is responsible for its markedly enhanced capability to inhibit RNA synthesis.

The results of our in vitro experiments suggest that an important factor responsible for the markedly higher antiproliferative potency of p-DOX compared to parental DOX is capability of the former anthracycline to inhibit downstream cellular processes which process DNA damaged by this drug and involve separation of complementary strands of DNA, such as DNA unwinding by helicases or RNA polymerases and perhaps also by DNA repair proteins.

We demonstrate in this work (Fig. 8) that p-DOX readily forms in double-helical DNA interstrand CLs even in absence of formaldehyde or formaldehyde releasing agents (Fig. 8B) whereas parental DOX does not (Fig. 8A). In general, CLs connecting two complementary strands of double-helical DNA impede separation of complementary strands of DNA. Thus, it seems reasonable to conclude that capability of p-DOX to form interstrand CLs is particularly responsible for cytotoxic processes in cells (treated with this agent) involving inhibition of separation of complementary strands of DNA. The results of the present work suggest that among such processes might be those involving helicases or RNA polymerases, but very likely not those involving topoII.

Taken together, the results of the present work indicate that the blockade of DNA helicases by DNA adducts of p-DOX may be central in the mechanism of action of this anthracycline associated with its markedly enhanced activity as an anticancer drug. Thus, it can be also anticipated that by switching the mechanism of action of DOX by its conversion to p-DOX, not only a reduced concentration of drug is required to achieve similar cell kill as compared to parental DOX, but also resistance to DOX may be overcome [50]. 


\section{Acknowledgements}

This research was supported by the Czech Science Foundation (P301/09/H004). The authors also acknowledge that their participation in the EU COST Action D39 has enabled them to exchange regularly their most recent ideas in the field of anticancer drugs with several European colleagues.

\section{Appendix A. Supplementary data}

Supplementary data associated with this article can be found, in the online version, at doi: ...

\section{References}

[1] Burden DA, Osheroff N. Mechanism of action of eukaryotic topoisomerase II and drugs targeted to the enzyme. Biochim Biophys Acta 1998;1400:139-54.

[2] Minotti G, Menna P, Salvatorelli E, Cairo G, Gianni L. Anthracyclines: Molecular advances and pharmacologic developments in antitumor activity and cardiotoxicity. Pharmacol Rev 2004;56:185-229.

[3] Cutts SM, Nudelman A, Rephaeli A, Phillips DR. The power and potential of doxorubicinDNA adducts. IUBMB Life 2005;57:73-81.

[4] Gewirtz DA. A critical evaluation of the mechanisms of action proposed for the antitumor effects of the anthracycline antibiotics adriamycin and daunorubicin. Biochem Pharmacol $1999 ; 57: 727-41$. 
[5] Swift LP, Cutts SM, Rephaeli A, Nudelman A, Phillips DR. Activation of adriamycin by the $\mathrm{pH}$-dependent formaldehyde-releasing prodrug hexamethylenetetramine. Mol Cancer Ther 2003;2:189-98.

[6] Taatjes DJ, Fenick DJ, Koch TH. Nuclear targeting and nuclear retention of anthracyclineformaldehyde conjugates implicates DNA covalent bonding in the cytotoxic mechanism of anthracyclines. Chem Res Toxicol 1999;12:588-96.

[7] Post GC, Barthel BL, Burkhart DJ, Hagadorn JR, Koch TH. Doxazolidine, a proposed active metabolite of doxorubicin that cross-links DNA. J Med Chem 2005;48:7648-57.

[8] Nagy A, Aramatis P, Schally AV. High yield conversion of doxorubicin to 2pyrrolinodoxorubicin, an analog 500-1000 times more potent: Structure-activity relationship of daunosamine-modified derivatives of doxorubicin. Proc Natl Acad Sci USA 1996;93:2464-9.

[9] Bachur NR, Lun L, Sun PM, Trubey CM, Elliott EE, Egorin MJ, et al. Anthracycline antibiotic blockade of SV40 T antigen helicase action. Biochem Pharmacol 1998;55:102534.

[10] Tuteja R, Tuteja N, Malhotra P, Singh Chauhan V. Replication fork-stimulated eIF-4A from Plasmodium cynomolgi unwinds DNA in the $3^{\prime}$ to $5^{\prime}$ direction and is inhibited by DNA-interacting compounds. Arch Biochem Biophys 2003;414:108-14.

[11] Suntornthiticharoen P, Petmitr S, Chavalitshewinkoon-Petmitr P. Purification and characterization of a novel 3 '-5 ' DNA helicase from Plasmodium falciparum and its sensitivity to anthracycline antibiotics. Parasitology 2006;133:389-98.

[12] Matson SW, Kaiserrogers KA. DNA helicases. Annu Rev Biochem 1990;59:289-329. 
[13] Lohman TM, Bjornson KP. Mechanisms of helicase-catalyzed DNA unwinding. Annu Rev Biochem 1996;65:169-214.

[14] Ellis NA. DNA helicases in inherited human disorders. Curr Opin Genet Dev 1997;7:35463.

[15] Brabec V, Palecek E. The influence of salts and $\mathrm{pH}$ on polarographic currents produced by denatured DNA. Biophysik 1970;6:290-300.

[16] Brabec V, Palecek E. Interaction of nucleic acids with electrically charged surfaces. II. Conformational changes in double-helical polynucleotides. Biophys Chem 1976;4:76-92.

[17] Qu XG, Chaires JB. Analysis of drug-DNA binding data. In: Johnson ML, Brand L, editors. Numerical computer methods, Part C, San Diego/CA: Academic Press Inc; 2000, p. 353-69.

[18] Brosh RM, Li JL, Kenny MK, Karow JK, Cooper MP, Kureekattil RP, et al. Replication protein A physically interacts with the Bloom's syndrome protein and stimulates its helicase activity. J Biol Chem 2000;275:23500-8.

[19] Macris MA, Krejci L, Bussen W, Shimamoto A, Sung P. Biochemical characterization of the RECQ4 protein, mutated in Rothmund-Thomson syndrome. DNA Repair 2006;5:17280.

[20] Brabec V, Leng M. DNA interstrand cross-links of trans-diamminedichloroplatinum(II) are preferentially formed between guanine and complementary cytosine residues. Proc Natl Acad Sci USA 1993;90:5345-9.

[21] Berger JM, Gamblin SJ, Harrison SC, Wang JC. Structure and mechanism of DNA topoisomerase II. Nature 1996;379:225-32. 
[22] Moro S, Beretta GL, Dal Ben D, Nitiss J, Palumbo M, Capranico G. Interaction model for anthracycline activity against DNA topoisomerase II Biochemistry 2004;43:7503-13.

[23] Liu LF, Rowe TC, Yang L, Tewey KM, Chen GL. Cleavage of DNA by mammalian DNA topoisomerase II. J Biol Chem 1983;258:15365-70.

[24] Onda T, Toyoda E, Miyazaki O, Seno C, Kagaya S, Okamoto K, et al. NK314, a novel topoisomerase II inhibitor, induces rapid DNA double-strand breaks and exhibits superior antitumor effects against tumors resistant to other topoisomerase II inhibitors. Cancer Lett 2008;259:99-110.

[25] Pommier Y, Leo E, Zhang H, Marchand C. DNA topoisomerases and their poisoning by anticancer and antibacterial drugs. Chem Biol 2010;17:421-33.

[26] Ferrazzi E, Woynarowski JM, Arakali A, Brenner DE, Beerman TA. DNA damage and cytotoxicity induced by metabolites of anthracycline antibiotics, doxorubicin and idarubicin. Cancer Commun 1991;3:173-80.

[27] Capranico G, Supino R, Binaschi M, Capolongo L, Grandi M, Suarato A, et al. Influence of structural modifications at the $3^{\prime}$ and 4' positions of doxorubicin on the drug ability to trap topoisomerase II and to overcome multidrug resistance. Mol. Pharmacol. 199445 908-15

[28] Montaudon D, Pourquier P, Denois F, de Tinguy-Moreaud E, Lagarde P, Robert J. Differential stabilization of topoisomerase-II-DNA cleavable complexes by doxorubicin and etoposide in doxorubicin-resistant rat glioblastoma cells. Eur J Biochem 1997;245:30715.

[29] Pommier Y, Schwartz RE, Kohn KW, Zwelling LA. Formation and rejoining of deoxyribonucleic-acid double-strand breaks induced in isolated cell-nuclei by antineoplastic intercalating agents. Biochemistry 1984;23:3194-201. 
[30] Tewey KM, Chen GL, Nelson EM, Liu LF. Intercalative antitumor drugs interfere with the breakage-reunion reaction of mammalian DNA topoisomerase II. J Biol Chem 1984;259:9182-7.

[31] Taatjes DJ, Gaudiano G, Resing K, Koch TH. Redox pathway leading to the alkylation of DNA by the anthracycline, antitumor drugs adriamycin and daunomycin. J Med Chem 1997;40:1276-86.

[32] Cutts SM, Swift LP, Rephaeli A, Nudelman A, Phillips DR. Sequence specificity of Adriamycin-DNA adducts in human tumor cells. Mol Cancer Therapeutics 2003;2:661-70.

[33] Swift LP, Rephaeli A, Nudelman A, Phillips DR, Cutts SM. Doxorubicin-DNA adducts induce a non-topoisomerase II-mediated form of cell death. Cancer Res 2006;66:4863-71.

[34] Culliane C, van Rosmalen A, Philips DR. Does adriamycin induce interstrand cross-links in DNA? Biochemistry 1994;33:4632-8.

[35] Arola OJ, Saraste A, Pulkki K, Kallajoki M, Parvinen M, Voipio-Pulkki LM. Acute doxorubicin cardiotoxicity involves cardiomyocyte apoptosis. Cancer Res 2000;60:178992.

[36] Wouters KA, Kremer LCM, Miller TL, Herman EH, Lipshultz SE. Protecting against anthracycline-induced myocardial damage: a review of the most promising strategies. $\mathrm{Br} \mathrm{J}$ Haematol 2005;131:561-78.

[37] Lown JW. Anthracycline and anthraquinone anticancer agents: Current status and recent developments. Pharmacol Ther 1993;60:185-214.

[38] Binaschi M, Bigioni M, Cipollone A, Rossi C, Goso C, Maggi CA, et al. Anthracyclines: Selected new developments. Curr Med Chem - Anti-Cancer Agents 2001;1:113-30. 
[39] Cherif A, Farquhar D. N-(5,5-diacetoxypent-1-Y1)doxorubicin: A new intensely potent doxorubicin analog. J Med Chem 1992;35:3208-14.

[40] Sikic BI, Ehsan MN, Harker WG, Friend NF, Brown BW, Newman RA, et al. Dissociation of antitumor potency from anthracycline cardiotoxicity in a doxorubicin analog. Science 1985;228:1544-6.

[41] Rodger A, Marington R, Geeves MA, Hicks M, de Alwis L, Halsall DJ, et al. Looking at long molecules in solution: what happens when they are subjected to Couette flow? Phys Chem Chem Phys 2006;8:3161-71.

[42] Ihara T, Ikegami T, Fujii T, Kitamura Y, Sueda S, Takagi M, et al. Metal ion-directed cooperative DNA binding of small molecules. J Inorg Biochem 2006;100:1744-54.

[43] Chou P-J, Johnson WC. Base inclinations in natural and synthetic DNAs. J Am Chem Soc $1993 ; 115: 1205-14$.

[44] Suh D, Chaires JB. Criteria for the mode of binding of DNA binding agents. Bioorg Med Chem 1995;3:723-8.

[45] Grueso E, Prado-Gotor R. Thermodynamic and structural study of pyrene-1carboxaldehyde/DNA interactions by molecular spectroscopy: Probing intercalation and binding properties. Chem Phys 2010;373:186-92.

[46] Yu F, Johnson R, Hickey R, Wu Y, Malkas L. Helicase inhibition by anthracycline anticancer agents. Mol Pharmacol 1992;41:993-8.

[47] Meriwether WD, Bachur NR. Inhibition of DNA and RNA metabolism by daunorubicin and adriamycin in L1210 mouse leukemia. Cancer Res 1972;32:1137-42.

[48] Zunino F, Gambetta R, Di Marco A. The inhibition in vitro of DNA polymerase and RNA polymerases by daunomycin and adriamycin. Biochem Pharmacol 1975;24:309-11. 
[49] Momparler RL, Karon M, Siegel SE, Avila F. Effect of adriamycin on DNA, RNA and protein synthesis in cell-free systems and intact cells. Cancer Res 1976;36:2891-5.

[50] Studenovsky M, Ulbrich K, Ibrahimova M, Rihova B. Polymer conjugates of the highly potent cytostatic drug 2-pyrrolinodoxorubicin. Eur J Pharmaceut Sci 2011;42:156-63. 
1

2

3

Table 1. Summary of thermodynamic parameters for DOX and p-DOX binding to calf thymus DNA in BPES buffer

\begin{tabular}{lcc}
\hline drug & $K_{\mathrm{a}} \mathrm{M}^{-1 \mathrm{a}}$ & $\Delta G^{0}{ }_{25} \mathrm{~kJ} \mathrm{~mol}^{-1 \mathrm{~b}}$ \\
\hline DOX & $1.31 \times 10^{5}$ & 29.22 \\
p-DOX & $8.18 \times 10^{4}$ & 28.04
\end{tabular}

${ }^{\text {a }} K_{\mathrm{a}}$ denotes the DNA equilibrium binding constant, with reference to base pairs.

${ }^{\mathrm{b}} \Delta G^{0}{ }_{25}=-R T \ln K_{\mathrm{a}} ; \Delta G^{0}{ }_{25}$ is free energy at $25^{\circ} \mathrm{C}, T$ is the temperature in Kelvin, and $R$ is the universal gas constant $\left(8.314472 \mathrm{~J} \mathrm{~K}^{-1} \mathrm{~mol}^{-1}\right)$. 
Figure Captions

Fig. 1 - Structures of anthracyclines used in the present work.

Fig. 2 - Structure of p-DOX-DNA adducts ("virtual" interstrand cross-links) and chemistry of their formation where complementary DNA strands are in gray.

Fig. 3 - DNA binding isotherms for the interaction of DOX (empty squares) and p-DOX (full triangles) with calf thymus DNA in BPES buffer. The normalized fluorescence response is shown as a function of total DNA concentration. In these titrations, the ligand concentration was kept constant at $1 \mu \mathrm{M}$, while the DNA concentration was varied. Data fitting and determination of binding parameters were carried out using nonlinear least-squares analysis. The solid lines through the data show the best fitting curves.

Fig. 4 - Dependence of relative viscosity of calf thymus DNA on $r$. DNA was incubated with DOX (empty squares) and p-DOX (full triangles) in BPES buffer at $37^{\circ} \mathrm{C}$.

Fig. 5 - Inhibitory effect of DOX and p-DOX on decatenation of kinetoplast DNA (kDNA) by topoisomerase II. The topoII catalytic activity was determined by the decatenation assay. The kinetoplast catenated DNA was incubated with topoII in the presence or absence of DOX or pDOX, and decatenated DNAs were separated by agarose gel electrophoresis. For details, see Section 2.4. A. Kinetoplat DNA ( $8 \mu \mathrm{M}$ in bp) in presence of DOX or p-DOX $(0.12-4 \mu \mathrm{M}), 5 \mathrm{U}$ of human topoII, $3 \mathrm{mM}$ ATP in $20 \mu \mathrm{L}$ of the assay buffer A. Lanes: LN, linear kDNA marker; M, 
Fig. 6 - Effect of DNA modifications by DOX and p-DOX on DNA-unwinding activity of BLM helicase. The helicase reaction was performed as described in Materials and Methods. The structure of the DNA substrate is shown on the left side of each autoradiogram. Asterisk denotes the ${ }^{32} \mathrm{P}-$ labeled end. A, B, and C: Autoradiograms of $12 \%$ PAA native gels. Lanes 1: heatdenatured substrate; lanes 2: the substrate incubated without enzyme; lanes 3: reaction with enzyme and without any compound (Control). Lanes 3 - 10 in panels A, B and lanes 3 - 11 in panel C: the reactions with enzyme in the presence of different concentration of compounds used to modify DNA is indicated on the top of each panel. D. Quantitative evaluation of unwinding experiments. The unwinding efficiencies of BML in the presence of DOX (squares) and p-DOX (triangles) were quantified as described in the section Materials and Methods and plotted as a function of drug concentration. Values obtained after incubation of substrate without BLM were $<1 \%$ of the input radioactivity and were subtracted as background. 
Fig. 8 - Linearized pSP73 DNA (25 $\mu \mathrm{M}$ in bp) was incubated with DOX (A) or p-DOX (B) $(1 \mu \mathrm{M})$ at various $\mathrm{pH}$ (its value is indicated above each lane). The DNA was then subjected to a cleanup procedure and the pellet was resuspended in $0.03 \mathrm{M} \mathrm{NaOH}, 1 \mathrm{mM} \mathrm{Na} \mathrm{H}_{2}$ edta for $10 \mathrm{~min}$. Subsequently, samples were loaded onto a $1 \%$ agarose gel, and DNA was separated electrophoretically in TAE buffer [40 mM Tris-acetate, $1 \mathrm{mM} \mathrm{Na}_{2} \mathrm{H}_{2} \mathrm{edta}(\mathrm{pH}$ 8.0)]. Lanes: 1 (C1), pSP73 DNA incubated in the absence of the drug at pH 5.8; 2-7, pSP73 DNA incubated in the presence of the drug at $\mathrm{pH}$ indicated above each lane. dsDNA, double-stranded (interstrand crosslinked) DNA; ssDNA, single-stranded DNA. 


\title{
Supporting Information for
}

\section{DNA interactions of 2-pyrrolinodoxorubicin, a distinctively more potent daunosamine- modified analog of doxorubicin}

\author{
Jana Stepankova ${ }^{\text {a }}$, Martin Studenovsky ${ }^{\text {b }}$, Jaroslav Malina a, Jana \\ Kasparkova $^{c}$, Barbora Liskova ${ }^{a}$, Olga Novakova ${ }^{a}$, Karel Ulbrich ${ }^{\text {b }}$, \\ Viktor Brabec ${ }^{*}$, \\ ${ }^{a}$ Institute of Biophysics, Academy of Science of the Czech Republic, Kralovopolska 135, CZ- \\ 61265 Brno, Czech Republic \\ ${ }^{b}$ Institute of Macromolecular Chemistry, Academy of Science of the Czech Republic, Heyrovsky \\ square 2, CZ-16206, Prague 6, Czech Republic \\ ${ }^{c}$ Department of Biohysics, Faculty of Sciences, Palacky University, CZ-77146 Olomouc, Czech \\ Republic
}

\section{Circular and Linear Dichroism Spectroscopy.}

Isothermal circular dichroism (CD) spectra of DOX or p-DOX at the concentration of $4.2 \cdot 10^{-5} \mathrm{M}$ in the presence and absence of CT DNA $\left(0.27 \mathrm{mg} \mathrm{mL}^{-1}\right)$ were recorded at $25^{\circ} \mathrm{C}$ in BPES buffer by using a Jasco J-720 spectropolarimeter equipped with a thermoelectrically controlled cell holder. The cell pathlength was $3 \mathrm{~cm}$. CD spectra were recorded in the range of 300-600 $\mathrm{mm}$, in $0.2 \mathrm{~nm}$ increments with an averaging time of $0.5 \mathrm{~s}$. Flow LD spectra were collected by using a flow Couette cell in a Jasco J-720 spectropolarimeter adapted for LD measurements. Long molecules, such as DNA (minimum length of $\sim 250 \mathrm{bp}$ ), can be orientated in a flow Couette cell. The flow cell consists of a fixed outer cylinder and a rotating solid quartz inner cylinder, separated by a gap of $0.5 \mathrm{~mm}$, giving a total pathlength of $1 \mathrm{~mm}[1,2]$. LD spectra of CT DNA at the concentration of $96 \mu \mathrm{g} \mathrm{mL}^{-1}$ modified by DOX and p-DOX were recorded at $25^{\circ} \mathrm{C}$ in BPES buffer in the range of $220-600 \mathrm{~nm}$.

DOX and p-DOX yield the peaks in the CD spectrum corresponding to short axis transition at ca. 470 and $460 \mathrm{~nm}$, respectively and that to long axis transition at $~ 350$ and 355m, respectively (Fig. S1). A large red shift in the CD of the short and long axis transitions of both DOX and pDOX is observed upon binding to DNA. A strong red shift (bathochromic effect) and a decrease of the intensity (hypochromic effect) are known to be characteristic of intercalation. The peak corresponding to short axis transition is red shifted by approximately 30 and $18 \mathrm{~nm}$ for DOX and p-DOX, respectively and that corresponding to long axis transition is red shifted by approximately $40 \mathrm{~nm}$ for both anthracyclines. Similarly, the molar ellipticity for the long axis transition at $340 \mathrm{~nm}$ is observed to decrease in the presence of DNA for DOX whereas that at 

under conditions of total binding to DNA and at a nucleotide to drug ratio (r) of 20.
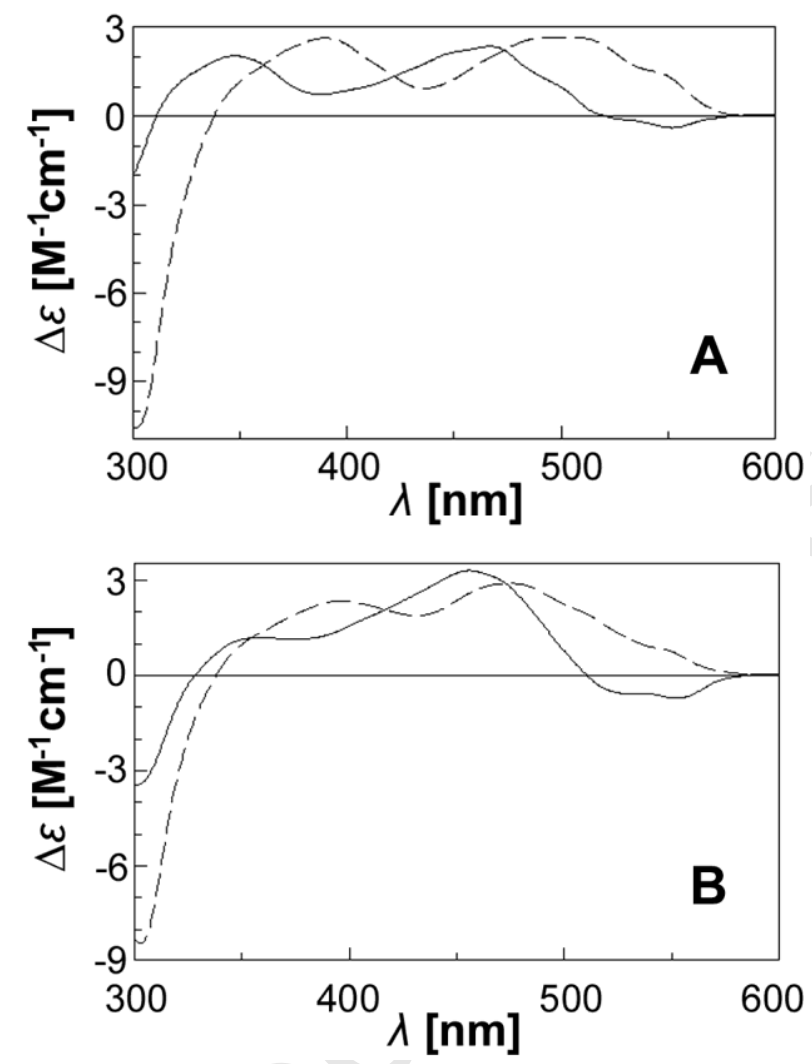

Figure S1. The circular dichroism (CD) spectra of DOX (A) and p-DOX (B) in the absence (full line) and presence (dashed line) of calf thymus DNA $\left(0.27 \mathrm{mg} \mathrm{mL}^{-1}\right), r=$ 0.05 . Absorption spectra were taken in $3-\mathrm{cm}$ cells at $25^{\circ} \mathrm{C}$ in BPES buffer.

Linear dichroism spectroscopy (LD) is the difference in absorption of linearly polarized light both parallel and perpendicular to a chosen plane and can be used to probe the orientation of molecules. Long molecules, such as DNA (minimum length of $\sim 250$ base pairs) can, in a flow Couette cell, be orientated through viscous drag [3]. The linearly polarized light is incident radial to the flow cell and perpendicular to the flow direction. Small unbound molecules are not orientated in the experiment and show no signal. Similarly molecules bound randomly to the CT DNA show no signal. However, molecules bound in a specific orientation with respect to the CT DNA will show a signal. DOX and p-DOX are too small to be orientated and thus show no intrinsic signal. Any signals that arise in the spectroscopic regions of the complex after the addition of CT DNA, therefore, indicate binding of the drug to the CT DNA in a specific orientation(s). For each of the anthracyclines (DOX and p-DOX) we observed bands in the 420$550 \mathrm{~nm}$ region in the LD spectra (Fig. S2A). Intensity of this band afforded by DNA modified by DOX was higher than that yielded by DNA modified by p-DOX (Fig. S2B). The negative DNA LD band (220-300 nm) increased in the amplitude upon drug addition (Fig. S2A). DOX increased the amplitude of this negative band slightly more than p-DOX. 

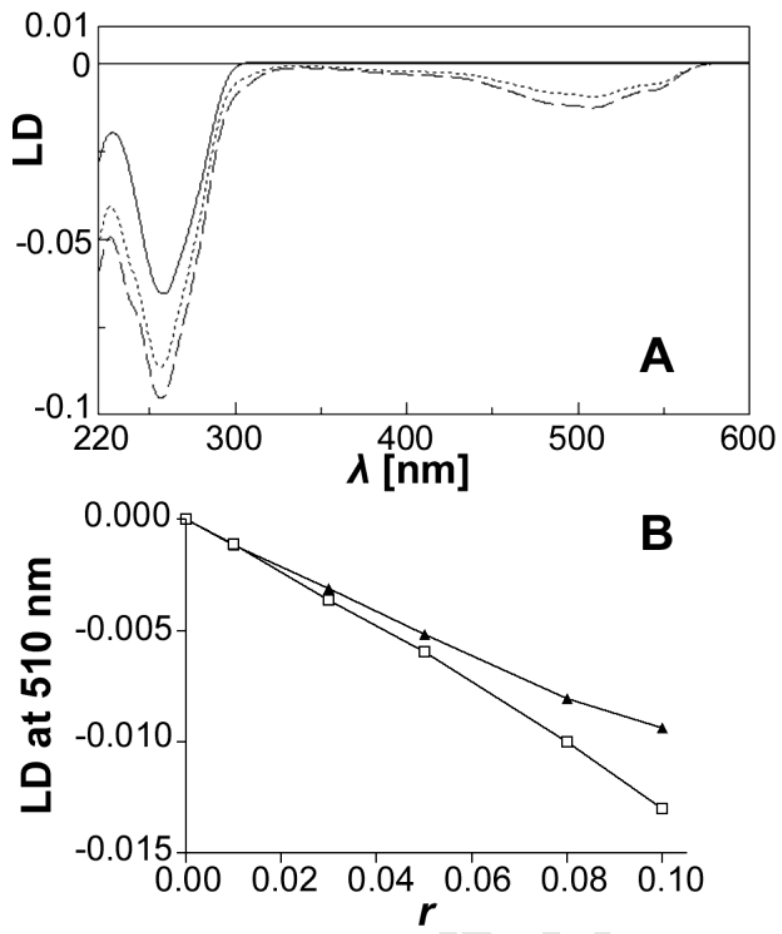

Figure S2. The linear dichroism (LD) spectra of calf thymus DNA $\left(98 \mu \mathrm{g} \mathrm{mL}^{-1}\right)$ incubated with DOX (A) or p-DOX (B) $r=0.1$ at $37^{\circ} \mathrm{C}$ in BPES buffer. DNA in absence (full line) and presence of DOX (dashed line) or p-DOX (dotted line0. (B) The effect of increasing $r$ on intensity of LD at $510 \mathrm{~nm}$ of DNA incubated with DOX (empty square) and p-DOX (full triangle.

\section{References}

[1] Rodger A. Linear dichroism. Methods Enzymol 1993;226:232-58.

[2] Rodger A, Norden B. Circular dichroism and linear dichroism. Oxford, New York, Tokyo: Oxford University Press, 1997.

[3] Rodger A, Marington R, Geeves MA, Hicks M, de Alwis L, Halsall DJ, et al. Looking at long molecules in solution: what happens when they are subjected to Couette flow? Phys Chem Chem Phys 2006;8:3161-71. 
Institute of Biophysics

Academy of Sciences of the Czech Republic, v.v.i.

Královopolská 135, CZ-61265 Brno

Czech Republic

From: prof. RNDr. Viktor Brabec, DrSc.

telephone: +420-541517 148 (direct); +420-541517 111 (operator);

fax: +420-541 240 499; e-mail: brabec@ibp.cz

\section{Professor}

Jacques G. Piette, Ph.D.

Editor

Biochemical Pharmacology

Manuscript reference number: BCP-D-11-00190

Dear Dr. Piette:

April 3, 2011

Thank you for your e-mail letter of March 18, 2011 concerning our manuscript submitted to the journal Biochemical Pharmacology:

“J. Stepankova, M. Studenovsky, J. Malina, J.Kasparkova, B. Liskova, O. Novakova, K. Ulbrich, V. Brabec: DNA interactions of 2-pyrrolinodoxorubicin, a distinctively more potent daunosamine-modified analog of doxorubicin"

In this letter you have kindly informed us that pending some revision, this report may ultimately be acceptable for publication in Biochemical Pharmacology.

I submitted electronically the revised manuscript ("marked" and "clean" copies) in which we made corrections as described in the text submitted in the "Respond to Reviewers" screen or in the document 'Revision-Rebuttal Notes'. Any text in the manuscript that has been changed or added in response to referees' comments has been marked in red in the marked copy.

I also confirm that the suppliers and their location are provided in the manuscript text for every chemical used in this study.

I hope that the revised manuscript now meets with your approval so that you will be able to authorize its publication in the journal Biochemical Pharmacology.

Yours sincerely,

Viktor Brabec 
Table 1. Summary of thermodynamic parameters for DOX and p-DOX binding to calf thymus DNA in BPES buffer

\begin{tabular}{lcc}
\hline drug & $K_{\mathrm{a}} \mathrm{M}^{-1 \mathrm{a}}$ & $\Delta G^{0}{ }_{25} \mathrm{~kJ} \mathrm{~mol}^{-1 \mathrm{~b}}$ \\
\hline DOX & $1.31 \times 10^{5}$ & 29.22 \\
p-DOX & $8.18 \times 10^{4}$ & 28.04
\end{tabular}

${ }^{\mathrm{a}} K_{\mathrm{a}}$ denotes the DNA equilibrium binding constant, with reference to base pairs.

${ }^{\mathrm{b}} \Delta G^{0}{ }_{25}=-R T \ln K_{\mathrm{a}} ; \Delta G^{0}{ }_{25}$ is free energy at $25^{\circ} \mathrm{C}, T$ is the temperature in Kelvin, and $R$ is the universal gas constant $\left(8.314472 \mathrm{~J} \mathrm{~K}^{-1} \mathrm{~mol}^{-1}\right)$. 


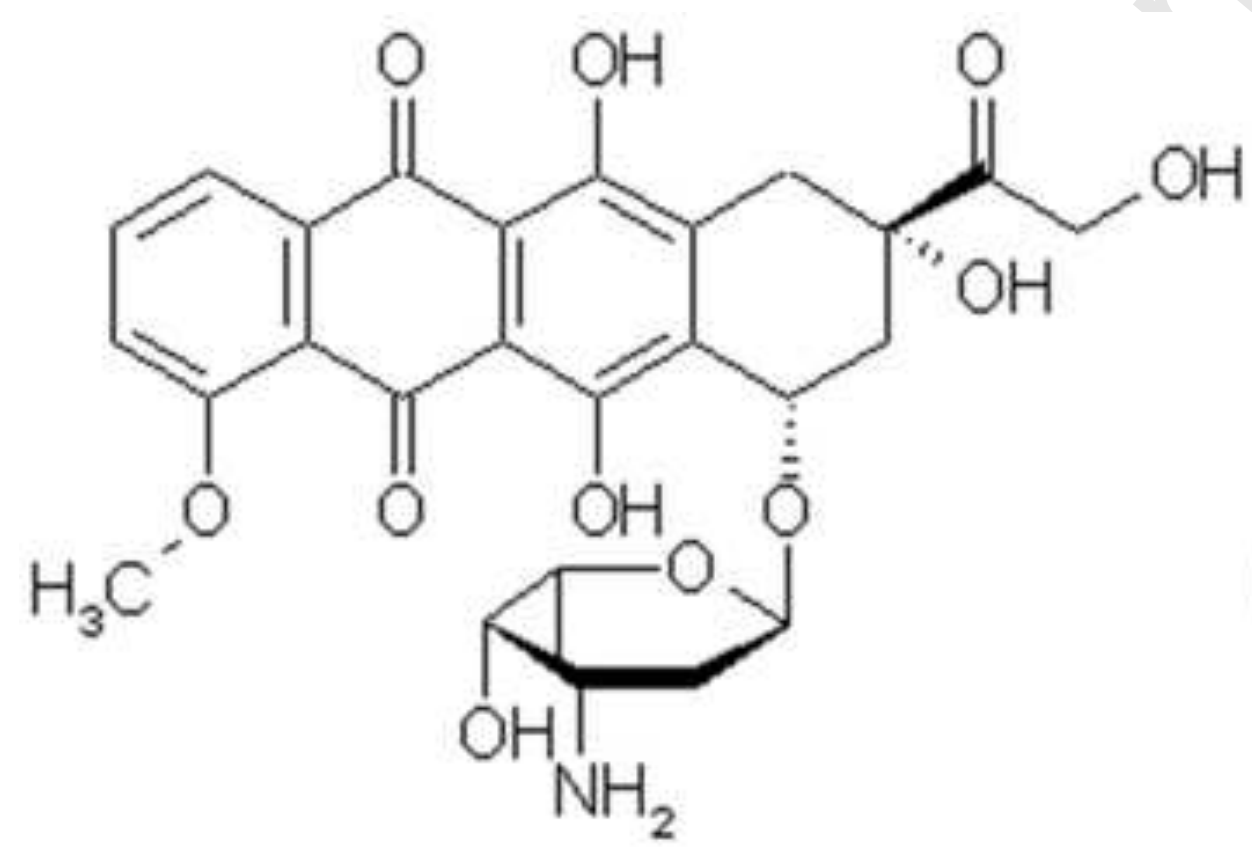

Doxorubicin (DOX)

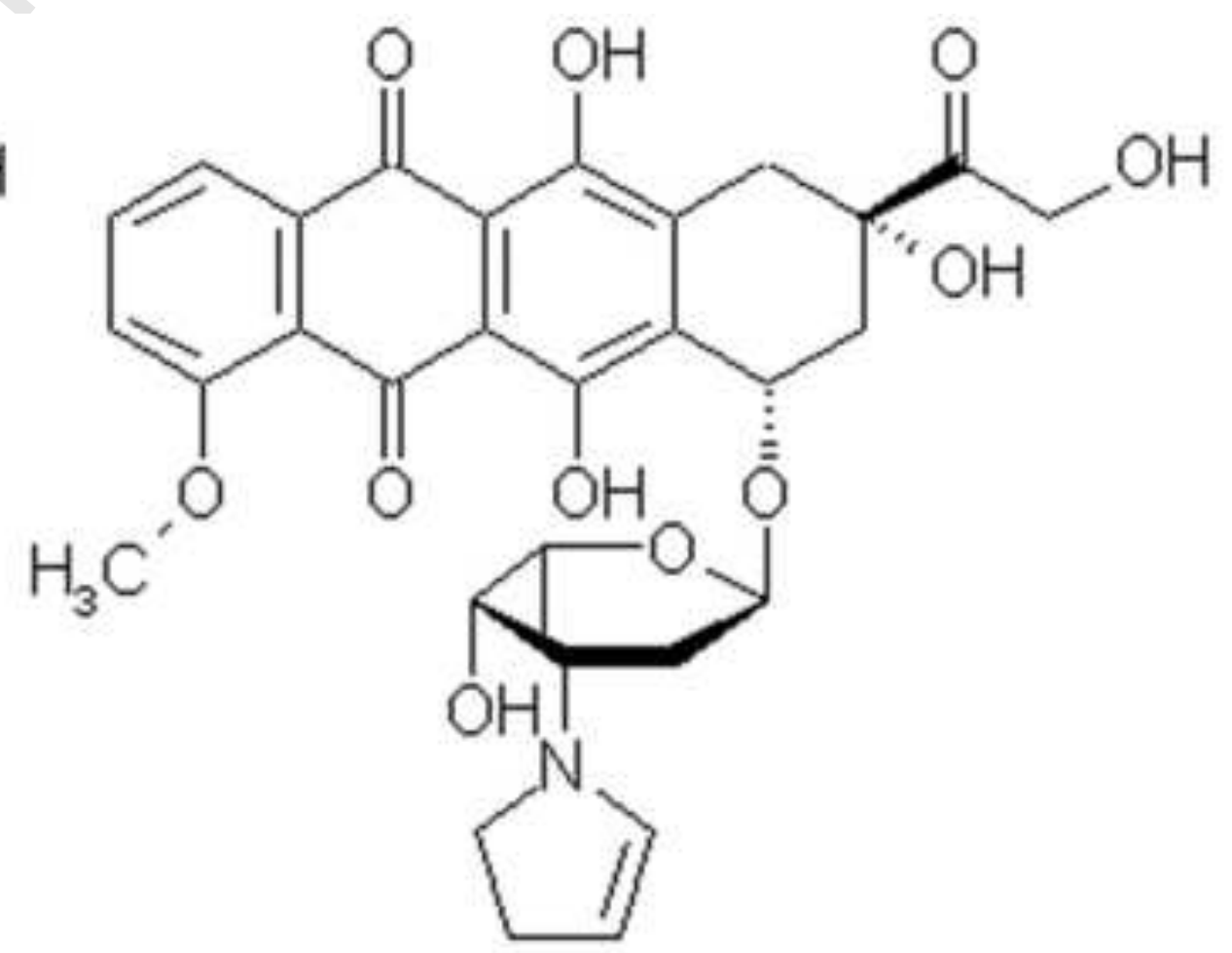

2-Pyrrolinodoxorubicin (p-DOX) 
<smiles>COc1cccc2c1C(=O)c1c(O)c3c(c(O)c1C2=O)C[C@@](O)(C(=O)CO)C[C@@H]3O[C@H]1C[C@@H](N2C=CCC2)[C@H](N2CCCC2)[C@H](O)[C@H]1O</smiles>

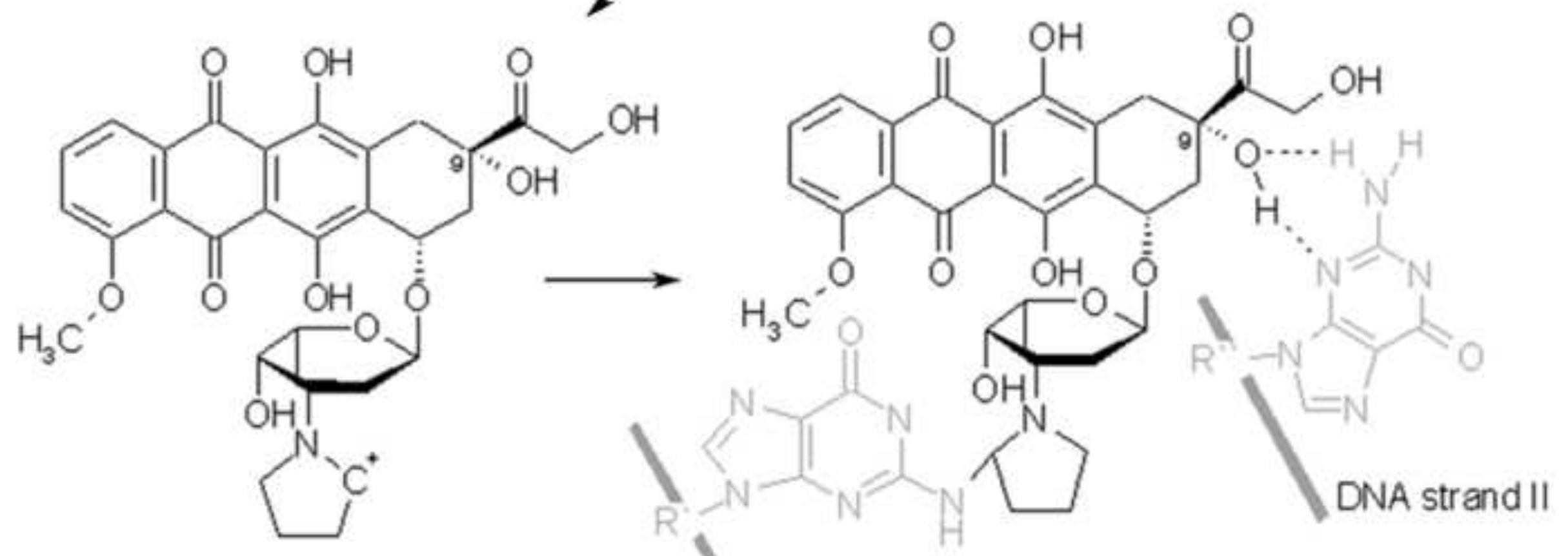

DNA strand I 


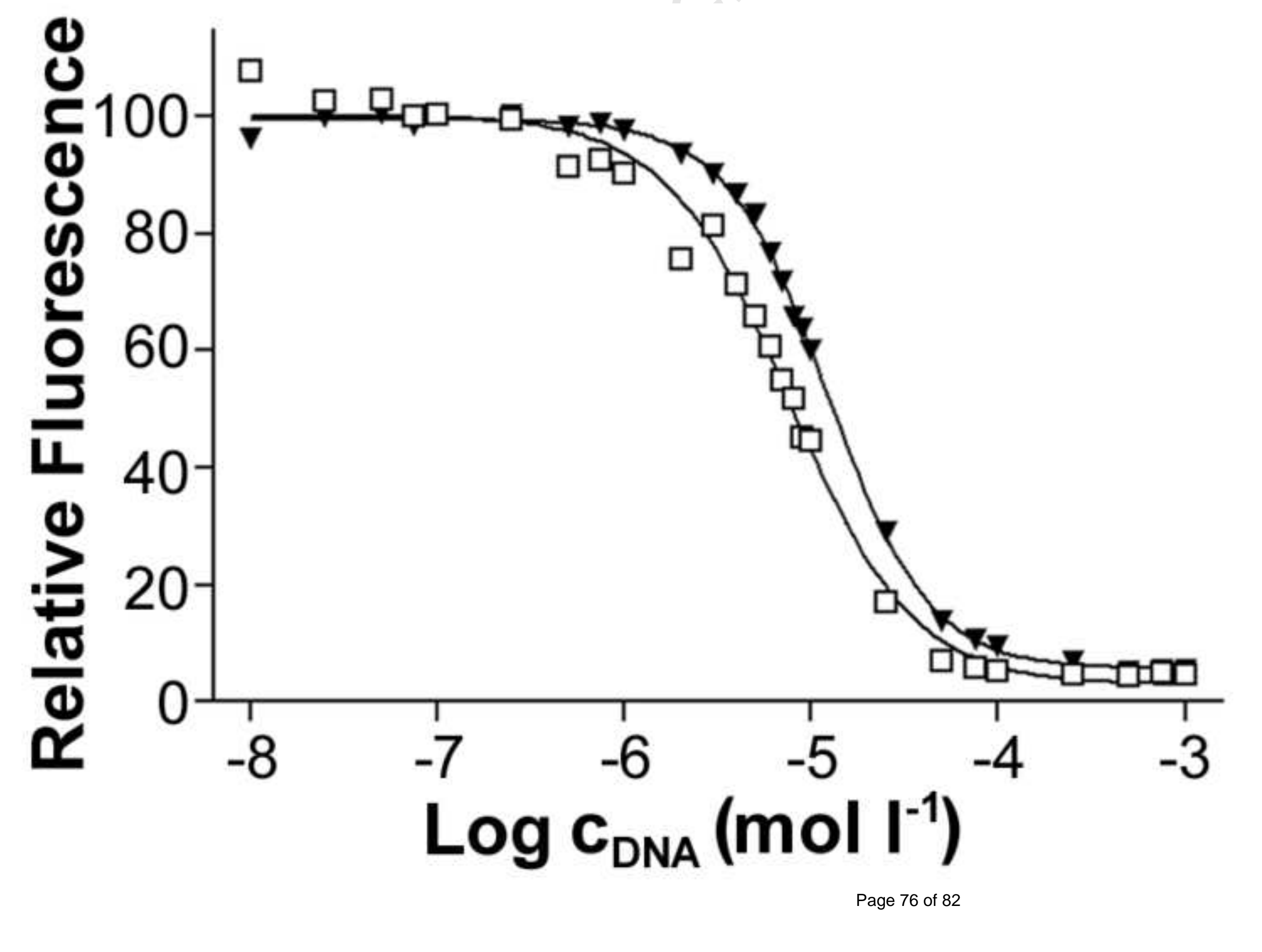



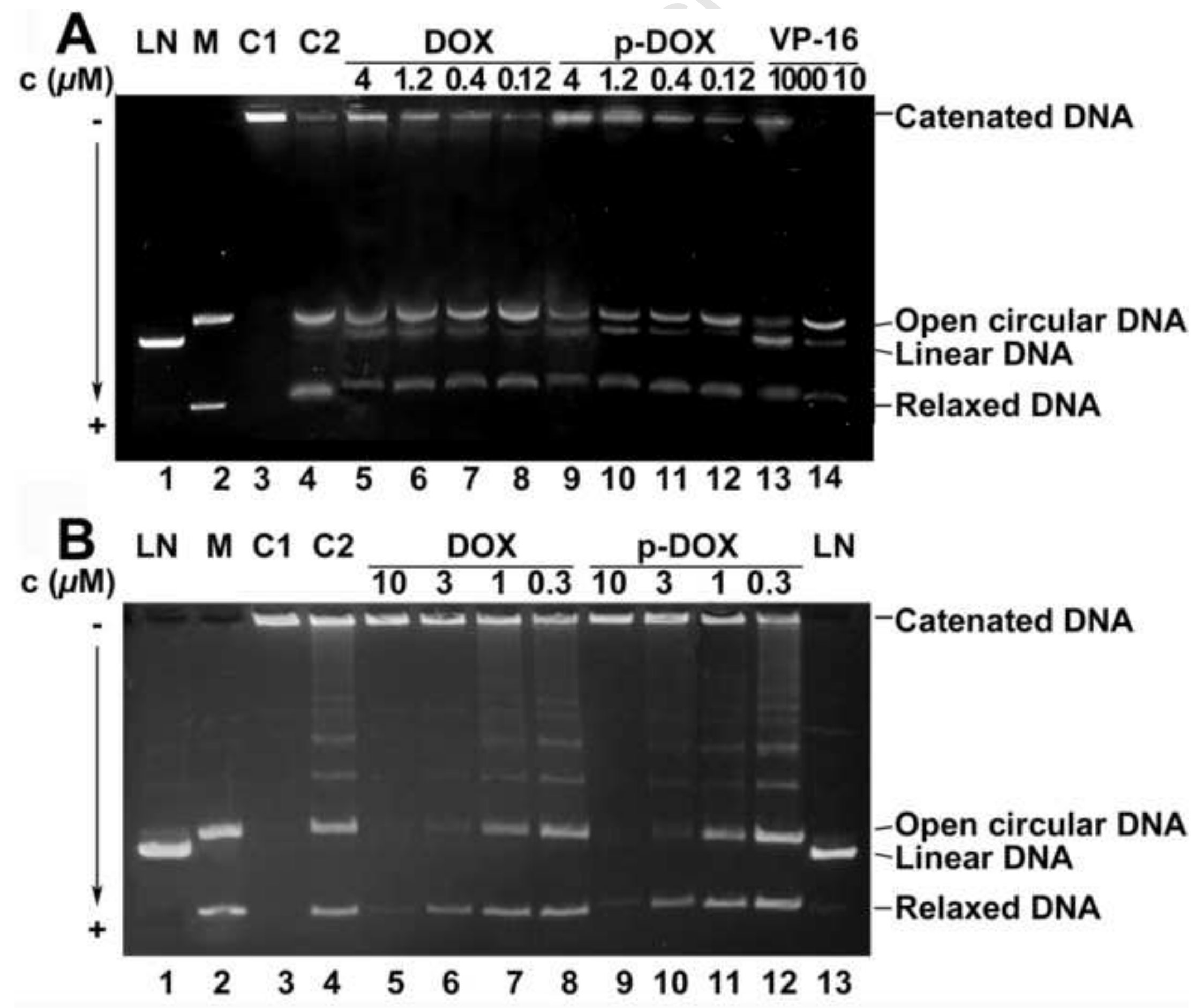


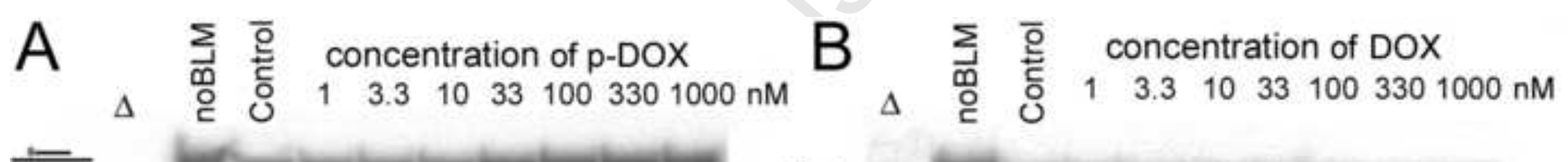

$\begin{array}{llllllllll}1 & 2 & 3 & 4 & 5 & 6 & 7 & 8 & 9 & 10\end{array}$

C

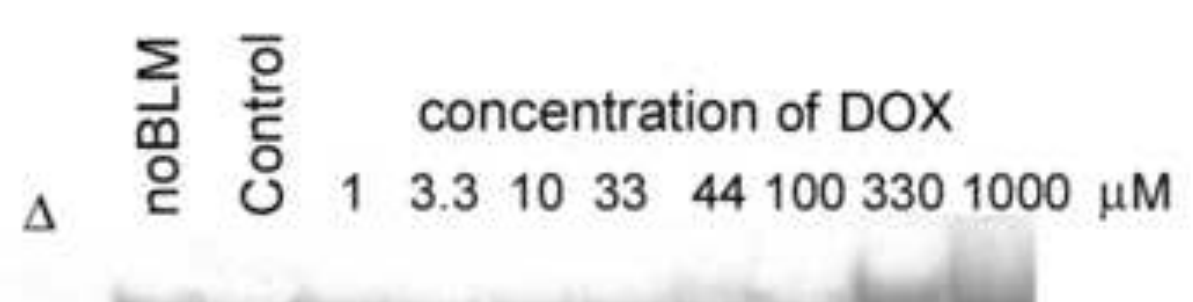

$\begin{array}{llllllllll}1 & 2 & 3 & 4 & 5 & 6 & 7 & 8 & 9 & 10\end{array}$

D

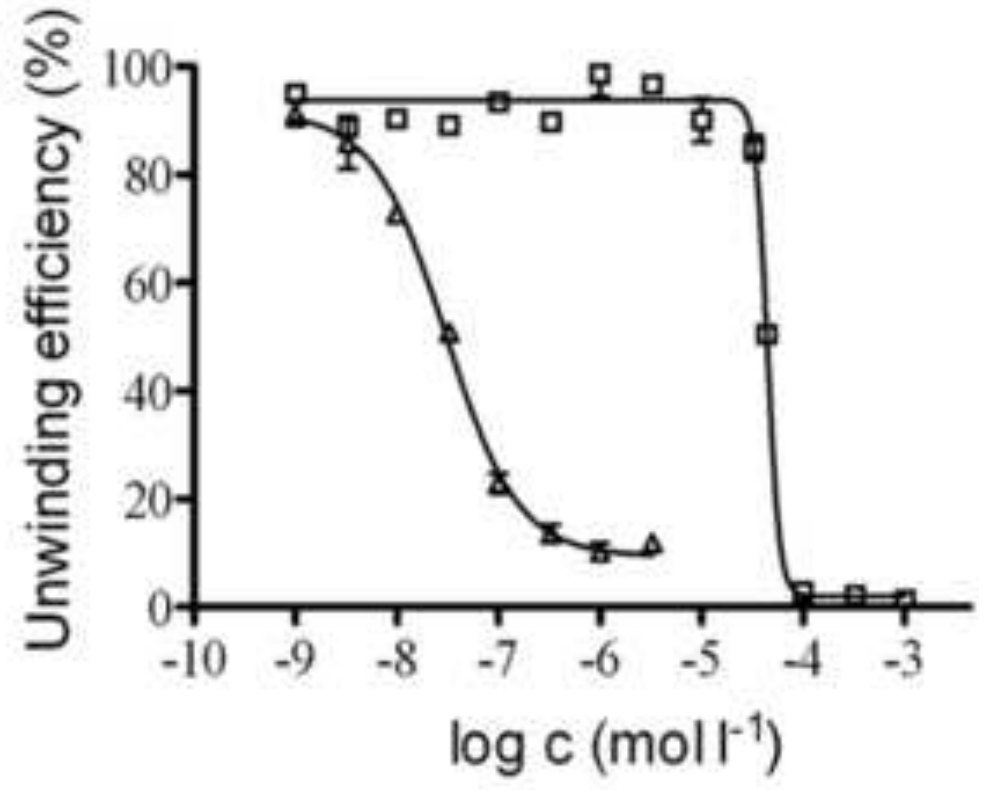


A

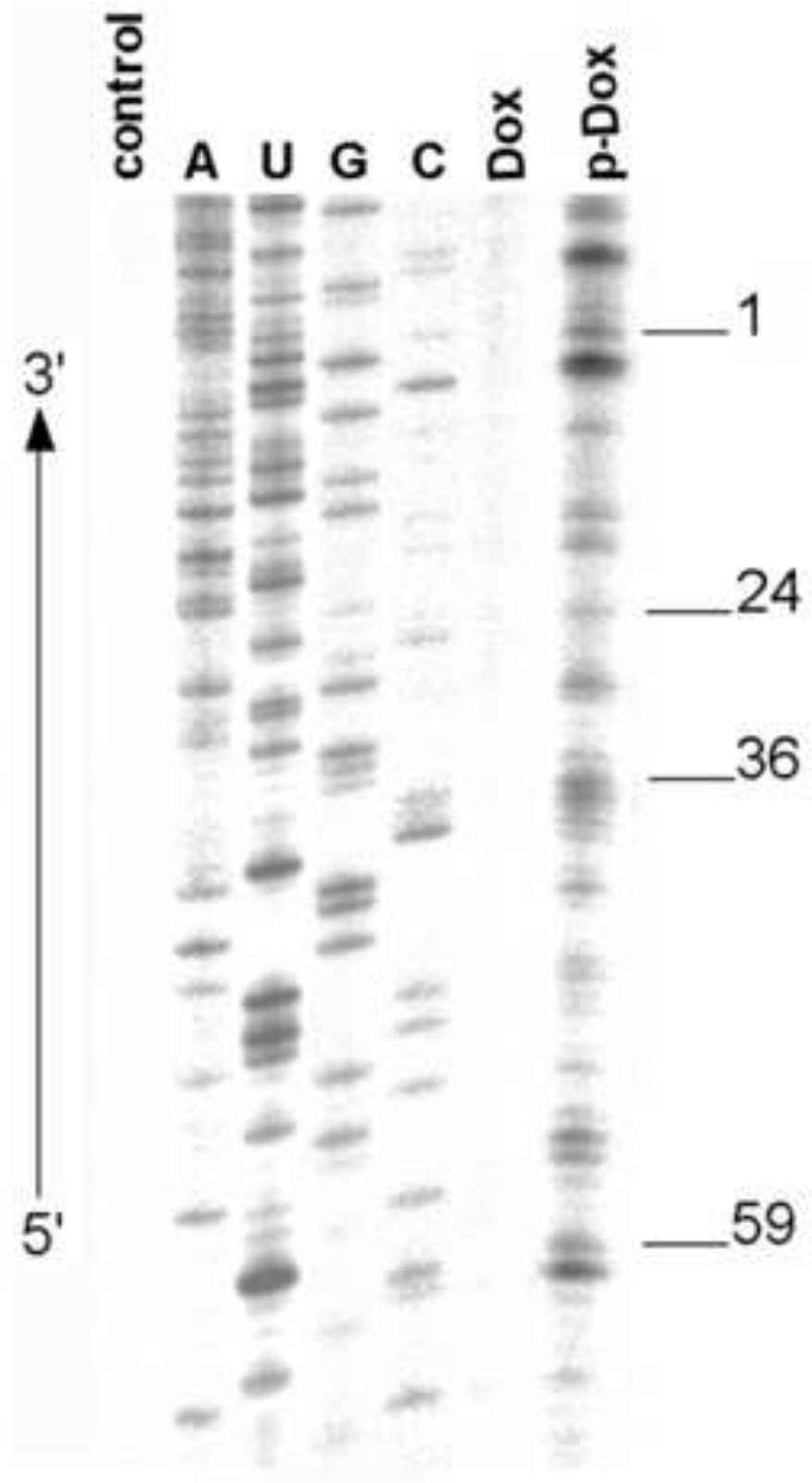

B

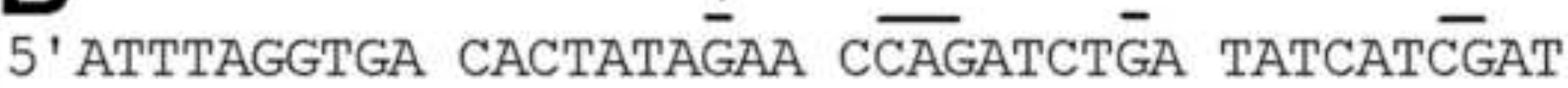
3' TAAATCCACT GTGATATCTT GGTCTAGACT ATAGTAGCTA

24

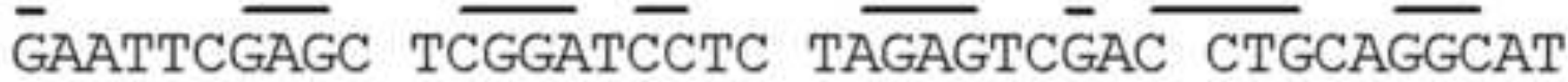
CTTAAGCTCG AGCCTAGGAG ATCTCAGCTG GACGTCCGTA

64

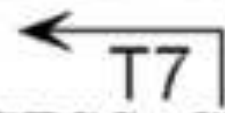

GCAAGCTTCA GCTGCTCGAG GCCGGTCTCC CTATA 3' CGTTCGAAGT CGACGAGCTC CGGCCAGAGG GATAT 5' 
$\begin{array}{lllllllllllllll}A_{\text {pH }} \text { C1 } & 5.3 & 5.8 & 6.3 & 6.8 & 7.3 & 7.7 & \text { B } 11 & 5.3 & 5.8 & 6.3 & 6.8 & 7.3 & 7.7\end{array}$

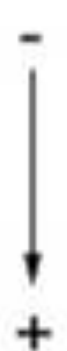

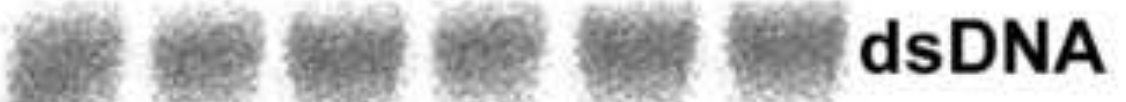
12
2
34
$\begin{array}{lll}5 & 6 & 7\end{array}$
12
34

ssDNA 


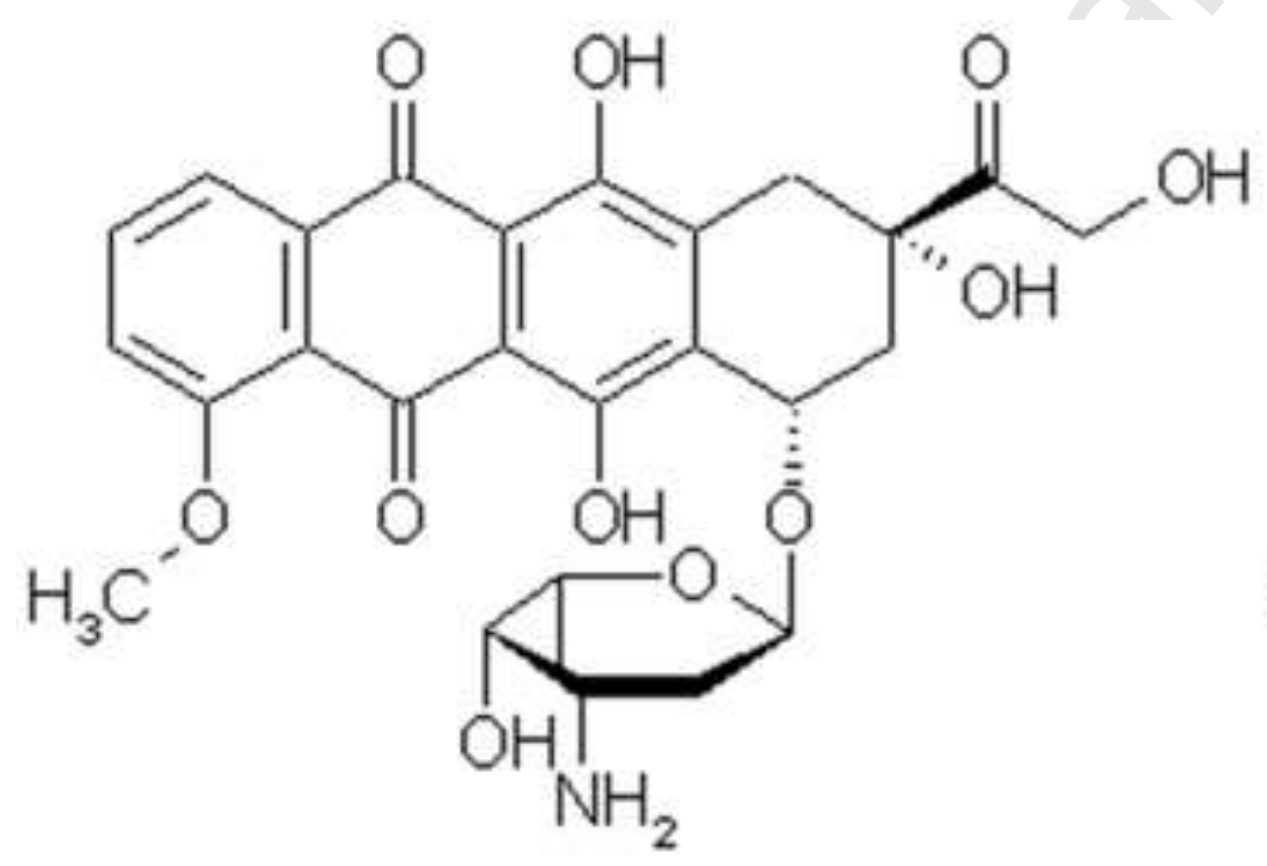

Doxorubicin

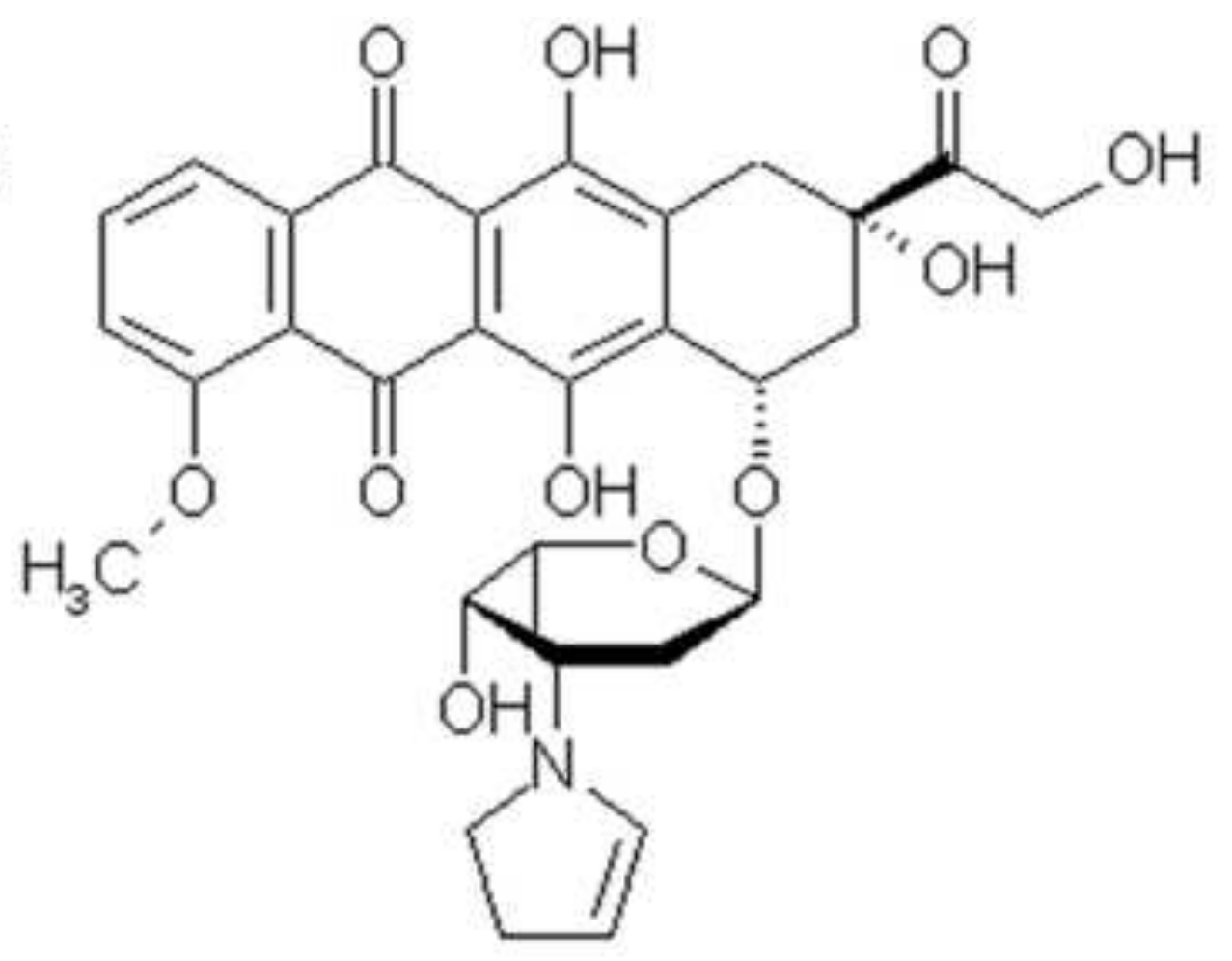

2-Pyrrolinodoxorubicin 